\title{
Facile and Green Synthesis of Saturated Cyclic Amines
}

\author{
Arruje Hameed ${ }^{1}$, Sadia Javed ${ }^{1}$, Razia Noreen ${ }^{1}$, Tayyaba Huma ${ }^{2}$, Sarosh Iqbal ${ }^{3}$, \\ Huma Umbreen ${ }^{4}$, Tahsin Gulzar ${ }^{3}$ and Tahir Farooq ${ }^{3, *}$ \\ 1 Department of Biochemistry, Government College University, Faisalabad 38900, Pakistan; \\ arrujetahirfsd@gmail.com (A.H.); diyajav1@yahoo.com (S.J.); itsrazia@yahoo.com (R.N.) \\ 2 Department of Bioinformatics and Biotechnology, Government College University, \\ Faisalabad 38900, Pakistan; tayyabahuma@gcuf.edu.pk \\ 3 Department of Applied Chemistry, Government College University, Faisalabad 38900, Pakistan; \\ sarosh.iqbal@yahoo.com (S.I.); tahsingulzar1@yahoo.com (T.G.) \\ 4 Department of Home Economics, Government College Women University, Faisalabad 38900, Pakistan; \\ huma.umbreen@yahoo.com \\ * Correspondence: tahirfarooqfsd@gmail.com; Tel.: +92-300-7939-458
}

Received: 19 September 2017; Accepted: 6 October 2017; Published: 12 October 2017

\begin{abstract}
Single-nitrogen containing saturated cyclic amines are an important part of both natural and synthetic bioactive compounds. A number of methodologies have been developed for the synthesis of aziridines, azetidines, pyrrolidines, piperidines, azepanes and azocanes. This review highlights some facile and green synthetic routes for the synthesis of unsubstituted, multisubstituted and highly functionalized saturated cyclic amines including one-pot, microwave assisted, metal-free, solvent-free and in aqueous media.
\end{abstract}

Keywords: cyclic amines; green synthesis; one-pot reactions; microwave assisted; solvent free

\section{Introduction}

Saturated cyclic amines are prominent bioactive motifs in many medicinal compounds and natural products (Figures 1 and 2). They are also attractive building blocks employed to construct other molecules of medicinal or biological interest [1]. A large number of such building blocks have also been used in polymers [2], copolymers [3], dyestuffs [4], reaction media [5], bases and chiral ligands, etc. [6-8]. Further, a large number of pharmacologically active natural and synthetic cyclic amines are in regular clinical use (Figure 3) [9]. They have been utilized as antibiotics, anticancer, analgesics, antidepressants, anti-HIV, anti-HCV agents, etc. [10,11]. A variety of cyclic amine-containing compounds also find applications as insecticides, pesticides, rodenticides and herbicides [12-16].

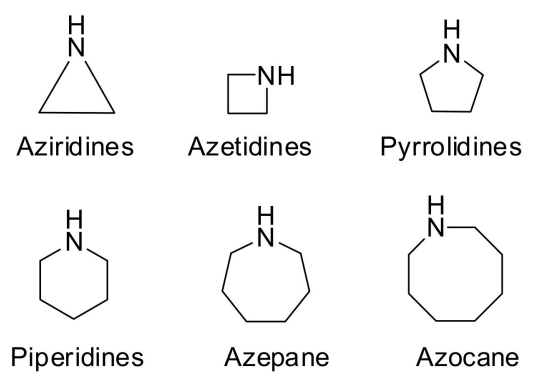

Figure 1. Saturated cyclic amines containing one-nitrogen atom. 
A broad scope of applications of the aforementioned saturated cyclic amines has revolutionized the synthetic methodologies used to access such compounds. A number of efficient synthetic methods have been developed over the past decades [17-19]. In recent years, quite a many environmentally benign methods have also been developed for the synthesis of saturated cyclic amines. This review aims to highlight the green synthetic methodologies including one-pot, multi-component, solvent-free, microwave-assisted and synthesis in aqueous media for single-nitrogen containing saturated cyclic amines.<smiles>CCCCCCCCCCCC1CCCC(C)N1</smiles>

Figure 2. Naturally compounds containing saturated cyclic amines.

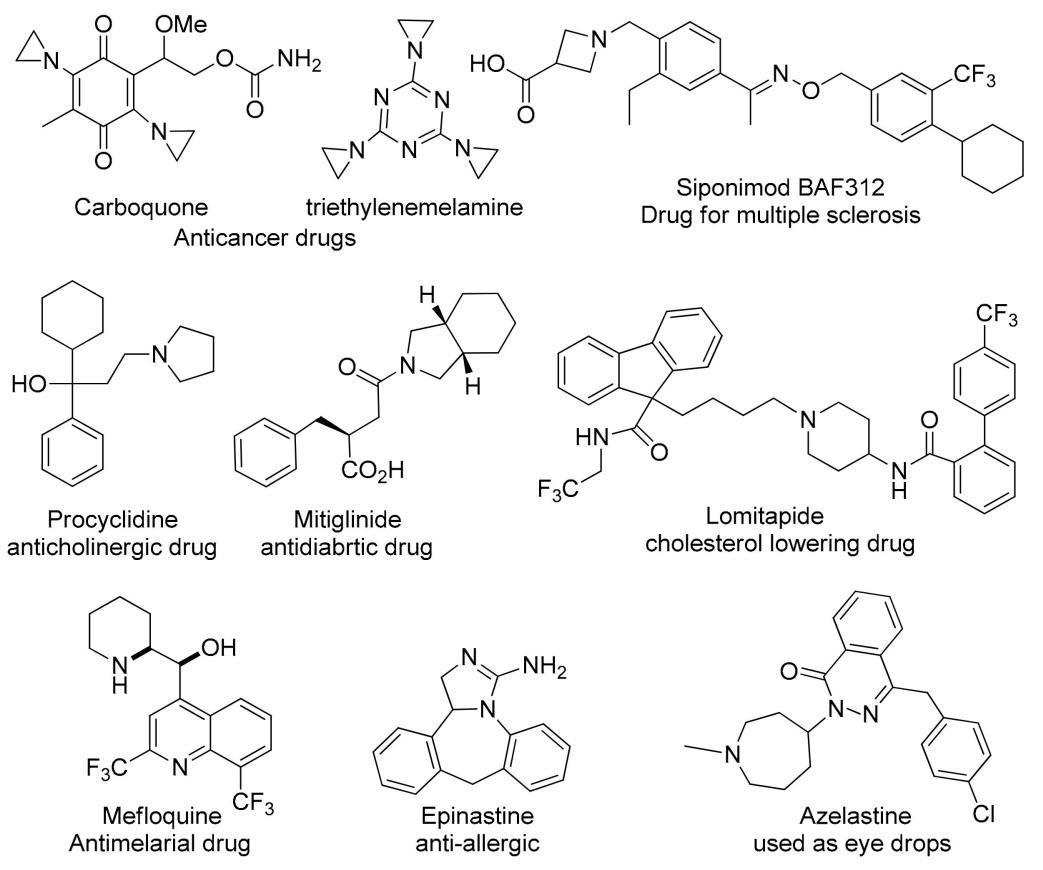

Figure 3. Clinical drugs containing saturated cyclic amine.

\section{Green Methods for Synthesis of Aziridines}

Bieber et al. presented a one-pot method for the synthesis of $N$-tosylaziridines from 2-amino-alcohols [20]. This one-pot transformation involves the tosylation and cyclization steps (Scheme 1). 
It was observed that highly substituted amino alcohols produce the corresponding aziridines in high yields in acetonitrile in the presence of $\mathrm{K}_{2} \mathrm{CO}_{3}$. High yields of less hindered aziridines were obtained from the corresponding alcohols when the reactions were performed in $\mathrm{H}_{2} \mathrm{O} / \mathrm{DCM}$ using $\mathrm{KOH}$ (Scheme 2).

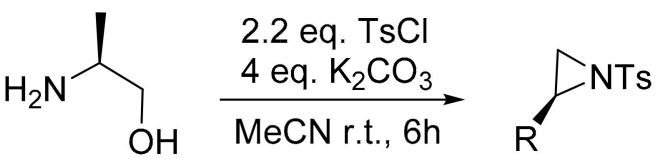

Scheme 1. One-pot synthesis of $N$-tosylaziridine.

Method A: TsCl, $\mathrm{K}_{2} \mathrm{CO}_{3}$. MeCN, $6 \mathrm{~h}$

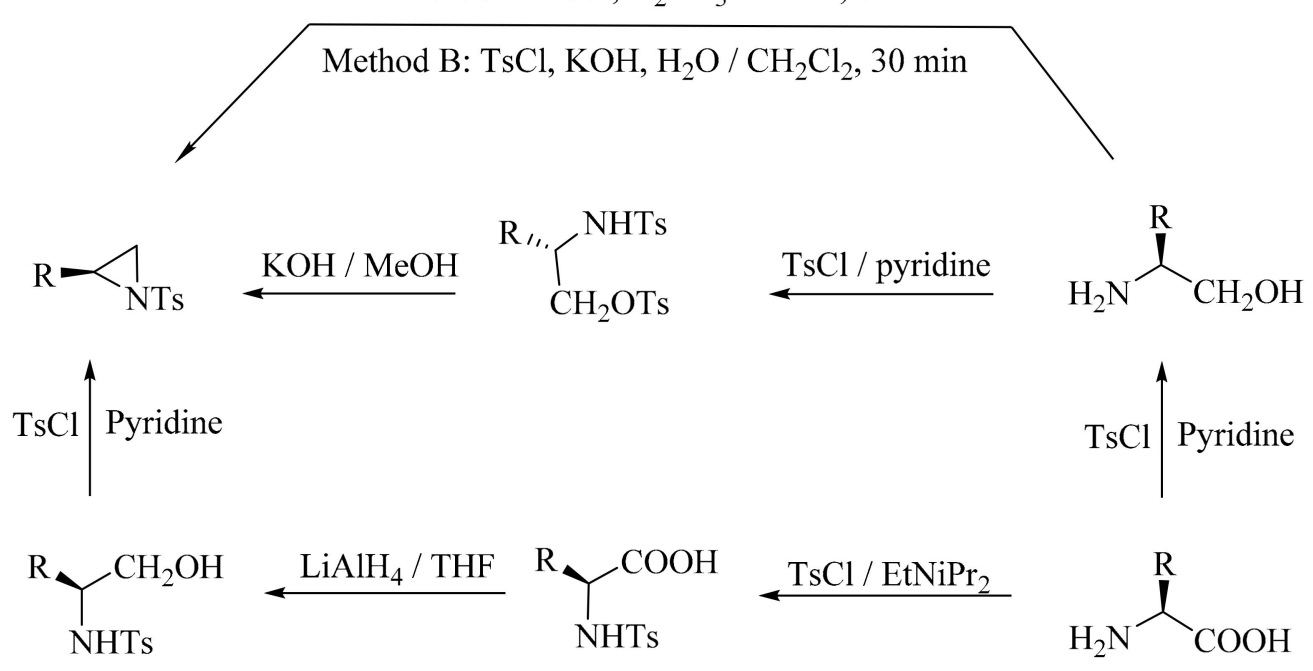

Scheme 2. Transformation of aminoalcohols to $N$-tosylaziridines.

Lohray and his research group used 1,2-cyclic sulfates for the one-pot synthesis of aminoalcohols and homochiral $\mathrm{N}$-substituted aziridines (Scheme 3). Cyclic sulfates react with primary amines to furnish $\beta$-aminosulfates which are converted to aziridines under basic conditions [21].

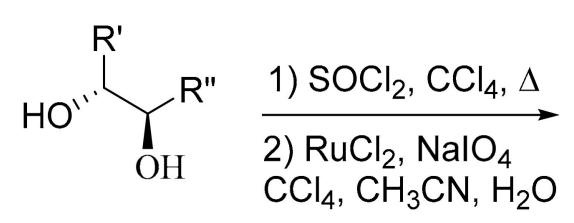
$\mathrm{CCl}_{4}, \mathrm{CH}_{3} \mathrm{CN}, \mathrm{H}_{2} \mathrm{O}$<smiles>[R]C(=O)C([R])[Se]</smiles>

$\underset{n-\mathrm{BuLi}, \mathrm{THF}}{\stackrel{\mathrm{RNH}_{2}, \mathrm{THF}, \Delta}{\longrightarrow}}$<smiles>[R]C1C([R])N1[R]</smiles>

$\mathrm{R}^{\prime}, \mathrm{R}^{\prime \prime}=$ alkyl, aryl or $\mathrm{H}$

Scheme 3. One-pot synthesis of aziridines from cyclic sulfates.

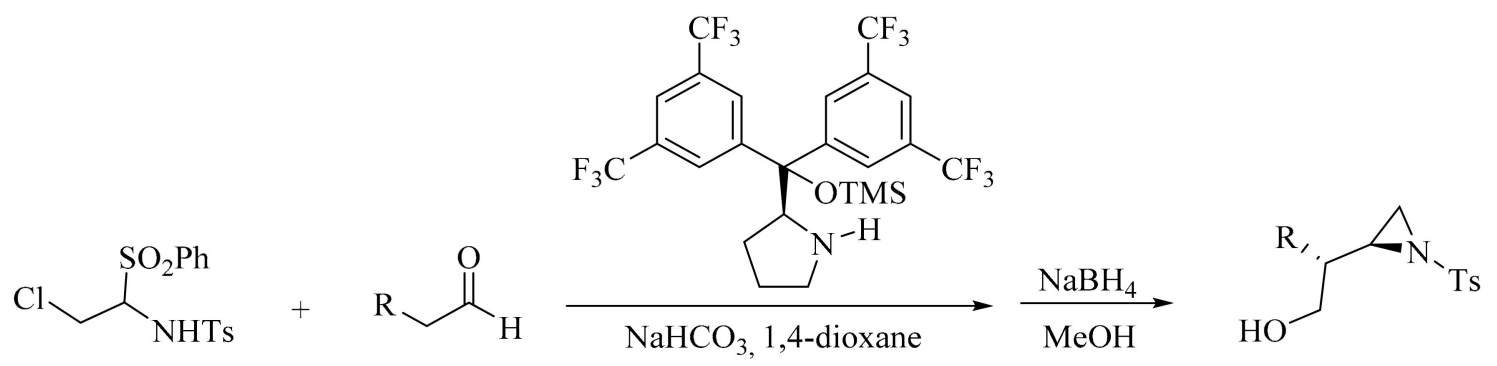

Scheme 4. Synthesis of chiral N-tosylated aziridines. 
Hayashi and his co-workers adopted a one-pot procedure to produce chiral aziridines with excellent enantio- and diastereoselectivities (Scheme 4). The sequential reactions include the desulfonylative generation of the $\mathrm{N}$-tosylated imine from chloroacetaldehyde, an asymmetric Mannich reaction mediated by diarylprolinol silyl ether, reduction and finally aziridine formation [22].

Using a one-pot synthesis strategy, a series of $(1 R, 2 S)$ - and $(1 S, 2 R)$-norephedrine and $(1 S, 2 S)$-pseudonorephedrine were converted into diastereomerically and enantiomerically enriched $\mathrm{N}$-sulfonylaziridines (Scheme 5). The reaction involves the $\mathrm{N}$-sulfonylation of the Ephedra alkaloid followed by $O$-sulfonylation with methanesulfonyl chloride [23]. The bis(sulfonyl) Ephedra derivatives afforded the corresponding $N$-sulfonylaziridines when they were treated with sodium hydroxide or hydrazine.

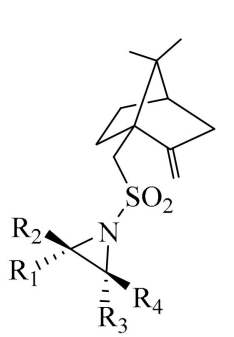

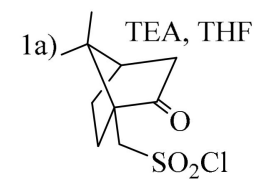
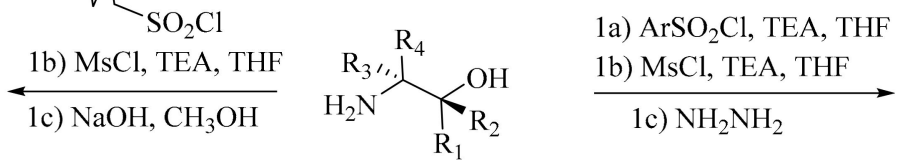

$$
\begin{aligned}
& \mathrm{R}^{1}=-\mathrm{Ph} ; \mathrm{R}^{2}=-\mathrm{H} ; \mathrm{R}^{3}=\mathrm{H} ; \mathrm{R}^{4}=-\mathrm{CH}_{3}(1 \mathrm{R}, 2 \mathrm{~S}) \text {-norephedrine } \\
& \mathrm{R}^{1}=-\mathrm{H} ; \mathrm{R}^{2}=-\mathrm{Ph} ; \mathrm{R}^{3}=-\mathrm{CH}_{3} ; \mathrm{R}^{4}=-\mathrm{H}(1 \mathrm{~S}, 2 \mathrm{R}) \text {-norephedrine } \\
& \mathrm{R}^{1}=-\mathrm{H} ; \mathrm{R}^{2}=-\mathrm{Ph} ; \mathrm{R}^{3}=-\mathrm{H} ; \mathrm{R}^{4}=-\mathrm{CH}_{3}(1 \mathrm{~S}, 2 \mathrm{~S}) \text {-pseudonorephedrine }
\end{aligned}
$$

Scheme 5. Synthesis of $N$-sulfonylaziridines.

Yadav et al. described a one-pot process for the synthesis of functionalized aziridines by the reaction of imines with phenacyl bromide derivatives. This high yielding stereoselective reaction is catalyzed by the tertiary amine DABCO (Scheme 6) [24].

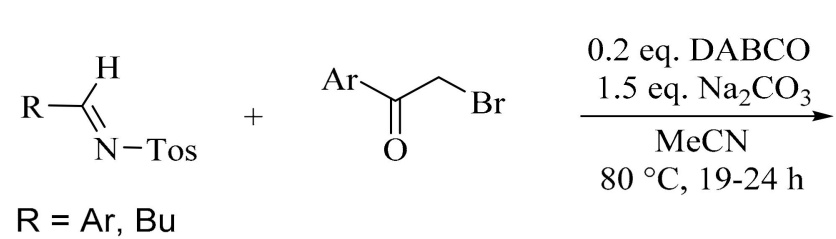

Scheme 6. Synthesis of functionalized aziridines.

Olugbeminiyi and his co-workers presented a one-pot methodology that affords chiral $N$-alkyl terminal aziridines with more than $90 \%$ ee (Scheme 7). During this three step reaction, aldehydes initially undergo an enantioselective $\alpha$-chlorination then reductive amination with primary amines and finally $\mathrm{SN}_{2}$ displacement results in the formation of the $\mathrm{N}$-alkyl terminal aziridines (Scheme 8) [25].

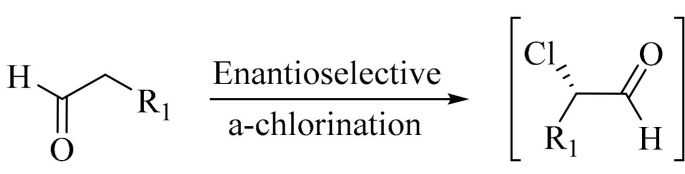

1) Reductive $\underset{\text { 2) Base-innduce }}{\stackrel{\text { amination }}{\longrightarrow}}$ cyclization<smiles>[R]C1CN1[R]</smiles>

$40-65 \%$ yield $56-96 \%$ ee

Scheme 7. Synthesis of $N$-alkyl terminal aziridines. 
A convenient method for the synthesis of $N$ - $\beta$-hydroxyethylaziridines was presented by Kim and his co-workers. $N$ - $\beta$-Hydroxyethylaziridines are known as important biological intermediates. They found that various epoxides undergo regioselective ring reactions with ethyleneimines. Under basic conditions, the ethyleneimine is generated in-situ from $\beta$-chloroethylamine in an aqueous environment (Scheme 9) [26].

Chiral $\beta$-fluoroamines via organocatalyst

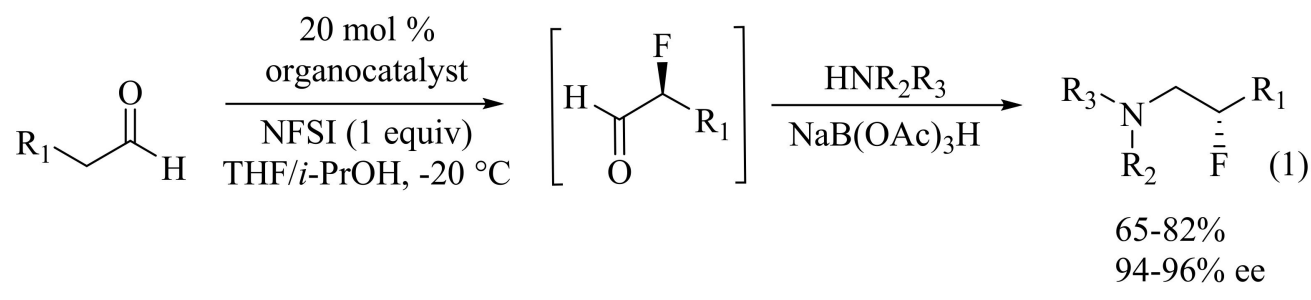

Chiral $N$-alkyle terminal aziridine via organocatalysis

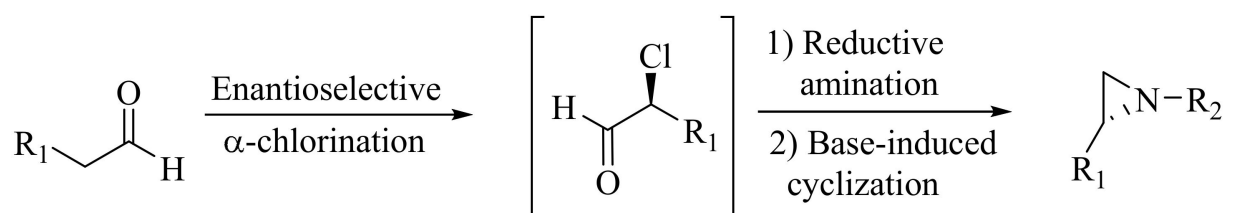

Scheme 8. Organocatalytic approach to chiral $N$-alkyl terminal aziridines.
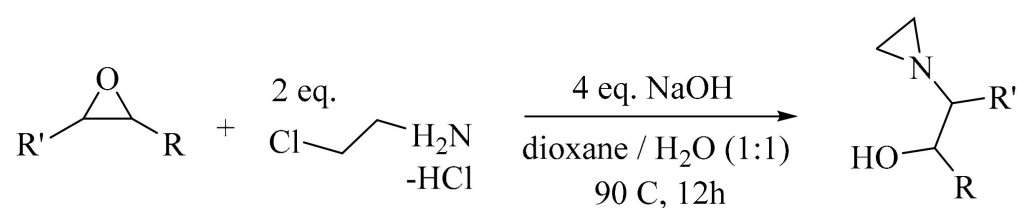

Scheme 9. Synthesis of $N$ - $\beta$-hydroxyethylaziridines.

Aziridines with a range of substituents were synthesized from the corresponding olefins in aqueous media. The iodine-catalyzed reaction requires quaternary ammonium salt in catalytic amounts to furnish good yield of highly pure product with simple work-up (Scheme 10) [27].

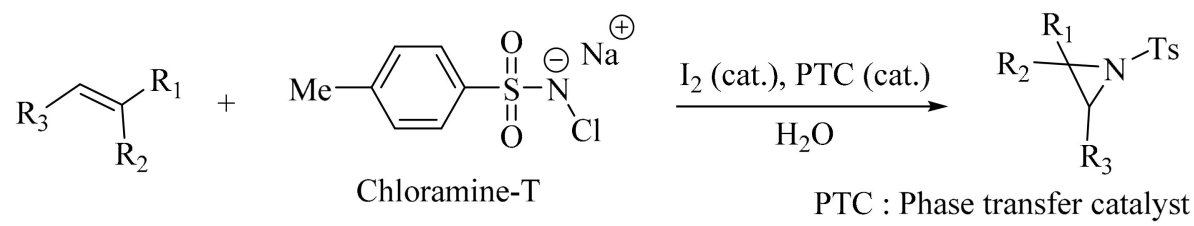

Scheme 10. Synthesis of substituted aziridines from olefins.

Kiyokawa and his research fellows presented that styrene derivatives do react with $\mathrm{N}$-tosyliminophenyliodinane to furnish $\mathrm{N}$-tosyl aziridines in good yields. This metal-free catalytic transformation is promoted by a combination of tetrabutylammonium iodide (TBAI) and $\mathrm{I}_{2}$ (Scheme 11). 


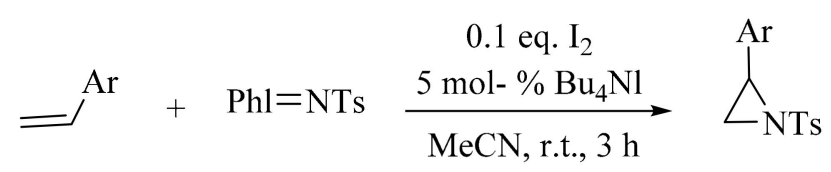

Scheme 11. Synthesis of $N$-tosyl aziridines from styrene.

During this reaction, both an extremely efficient catalyst $\mathrm{TBAI}_{3}$ and a real aziridination reagent called $\mathrm{N}, \mathrm{N}$-diiodotosylamide are produced in situ [28].

Imines react stereoselectively with ethyl diazoacetate in a montmorillonite K-10 solid acid catalyzed reaction to produce cis-aziridines in high yields (Scheme 12). This highly selective reaction accomplishes in short time under solvent-free conditions at room temperature furnishing the product in good yield [29].

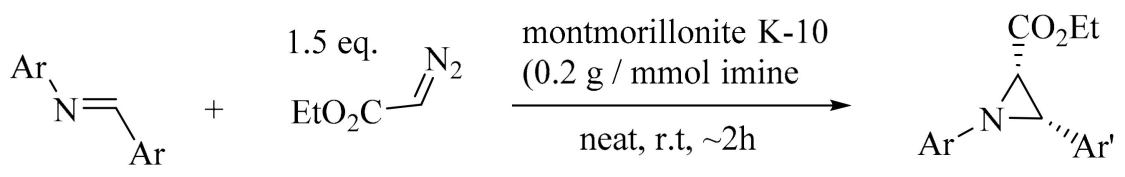

Scheme 12. Synthesis of cis-aziridines from imines.

\section{Green Synthesis of Azetidines}

Quinodoze and his colleagues demonstrated an easily practicable method to access enantiomerically pure $N$-aryl-2-cyanoazetidines with a range of substituents in high yield. This three-step transformation of $\beta$-amino alcohol proceeds through $\mathrm{Cu}$-catalyzed $\mathrm{N}$-arylation, $N$-cyanomethylation of aniline and mesylation followed by base induced ring closure (Schemes 13 and 14). The azetidine product with desired substitution pattern and diastereoselectivity signifies the versatility of this highly efficient reaction [30].

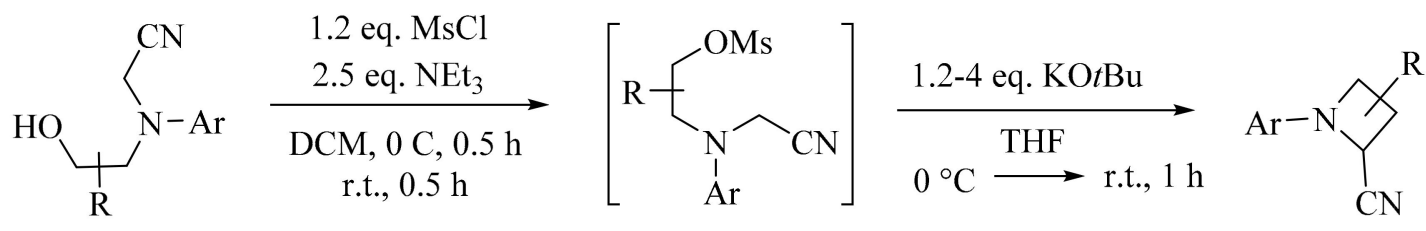

Scheme 13. Synthesis of $N$-aryl-2-cyanoazetidines.
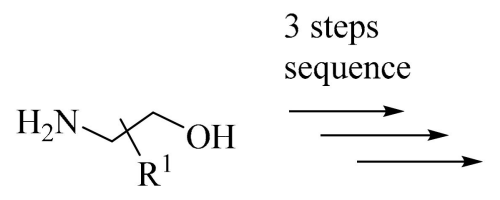<smiles>N#CC1CC1[Y]N</smiles>

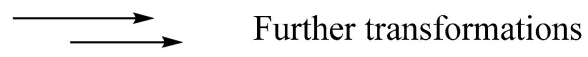

1) Predictable shape, substitution pattern and diastereoselectivity

2) High overall yield and high chemical diversity

Scheme 14. Sequential transformation of $\beta$-amino alcohols.

Kem et al. presented a robust one-pot procedure for the synthesis of $\alpha$-carbonylated $N$-sulfonylazetidines. In the presence of potassium carbonate, the reaction involves the nucleophilic addition mediated ring contraction reactions of $\alpha$-bromo $N$-sulfonylpyrrolidinones. They managed to synthesize variously substituted azitidine derivatives using nucleophiles like anilines, phenols and alcohols (Scheme 15) [31]. 


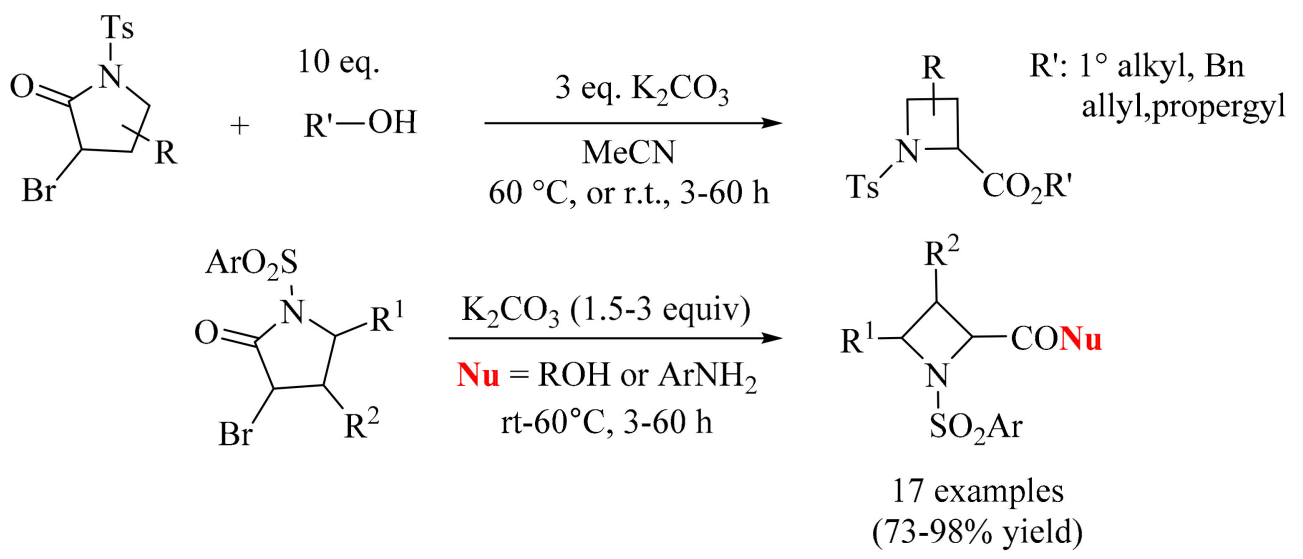

Scheme 15. Synthesis of $\alpha$-carbonylated $N$-sulfonylazetidines.

A general and efficient one-pot procedure has been presented by Malik et al. for the synthesis of 1-arenesulfonylazetidines. During this microwave-assisted reaction, the 1-arenesulfonylaziridines reacts with dimethylsulfoxonium methylide on a solid support of alumina to generate high yields of the product (Scheme 16) [32].

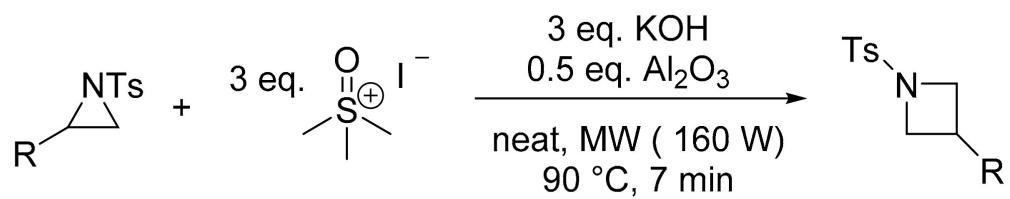

Scheme 16. Synthesis of 1-arenesulfonylazetidines.

An efficient, simple and one-pot cyclocondenation of primary amines and alkyl dihalides in an alkaline aqueous medium results in the formation of nitrogen-containing heterocycles. This microwave-assisted reaction is complete in just about $20 \mathrm{~min}$ (Scheme 17) [33].

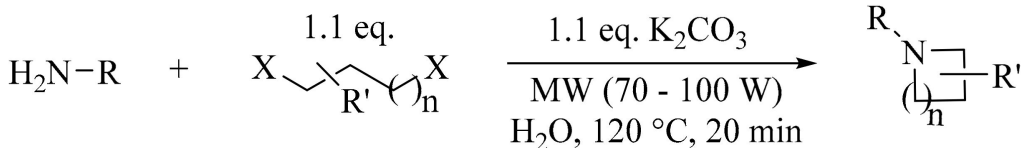

$$
\begin{aligned}
& \text { R: Ar, alkyl } \quad \mathrm{X} \text { : Br, Cl, OTs }
\end{aligned}
$$

Scheme 17. Microwave-assisted synthesis of cyclic amines.

Under very mild conditions, the carbodiimides, sulfonyl azides and terminal alkynes react to generate high yields of functionalized 2-(sulfonylimino)-4-(alkylimino)azetidine derivatives. This multi-component reaction is catalyzed by $\mathrm{Cu}$ (Scheme 18) [34].

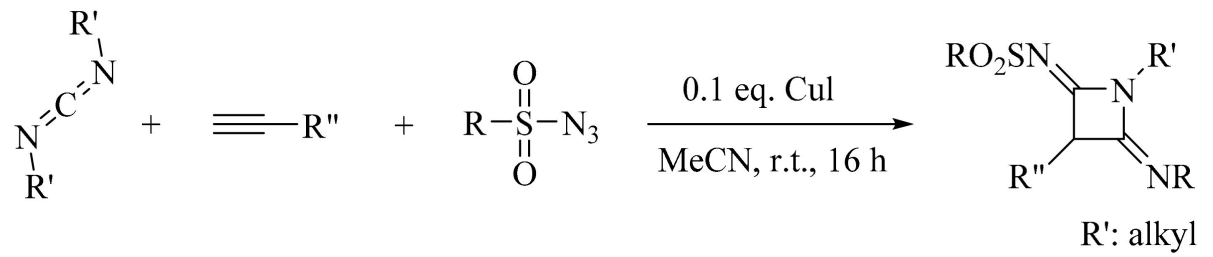

Scheme 18. Synthesis of functionalized 2-(sulfonylimino)-4-(alkylimino)azetidines. 
Hillier and his colleague accomplished the synthesis of 1,3-disubstituted azetidines through an undemanding method. During this reaction, the bistriflate of a 2-substituted-1,3-propanediol helps to achieve alkylation of primary amines leading to the formation of disubstituted azitidines [35]. The scope of this procedure has been well established using a variety of amines and 2-substituted-1,3-propanediols (Scheme 19).

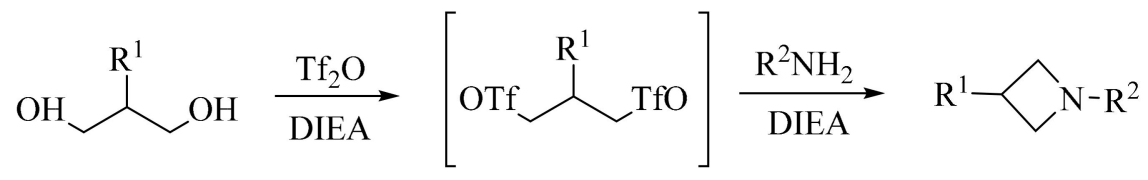

Scheme 19. Synthesis of disubstituted azitidines.

A variety of 3-substituted azetidine-2,4-diones were synthesized when aromatic aldehydes underwent a tandem cyclization with ethyl cyanoacetate. This Sn(II)-catalyzed reaction proceeds through Knoevenagel condensation, hydration and the C-N cyclization to furnished good to excellent yields of the product (Scheme 20). This atomically economic reaction showed a broad substrate scope [36].

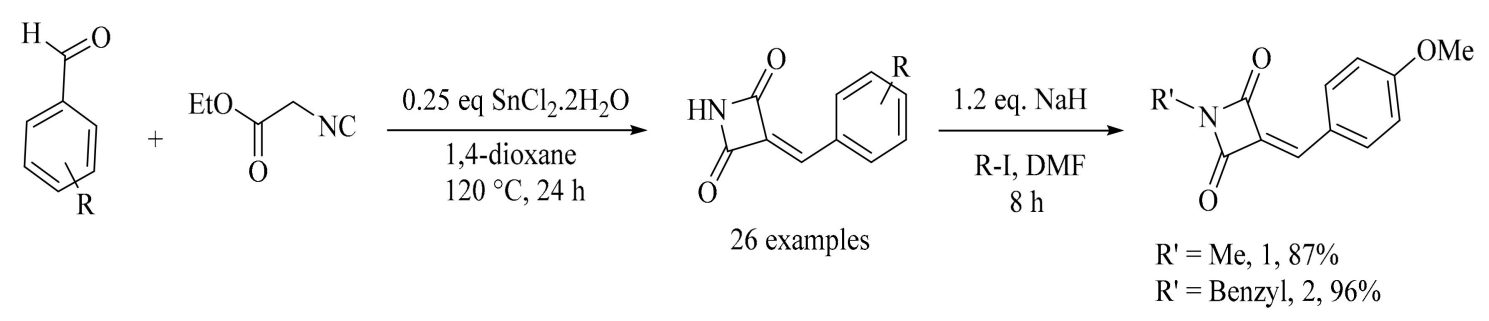

Scheme 20. Synthesis of 3-substituted azetidine-2,4-diones.

A facile, two-step and one-pot procedure provides an easy access to a range of chiral azetidine-piperidines by the reaction of chiral amines and piperidine chloroaldehyde [37]. Interestingly, the product retain the chirality of starting amine (Scheme 21).

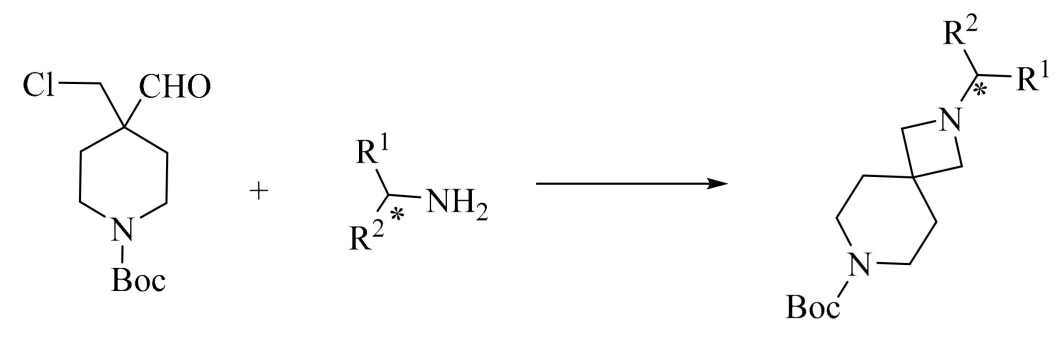

Scheme 21. Synthesis of chiral azetidine-piperidines.

Franck et al. described a straightforward and regioselective procedure for the synthesis of azetidines or pyrrolidines in good to excellent yields (Scheme 22). In this reaction the homoallylic amines undergo selenocyclization in respect of substitutions on double bond [38]. 
<smiles>[R]C=C([R])C([R])C([R])([R])NBr</smiles><smiles>[R]C1=[R17]([H])C([R])C12C([R])C([R])([R])N2Br</smiles>

azetidine<smiles>[R]C1C([R])N(Br)C([R])([R])C1[R]</smiles>

Pyrrolidine

Scheme 22. Regioselective procedure for the synthesis of azetidines or pyrrolidines.

Burkett and his colleagues presented a simple and facile microwave-assisted methodology for the accelerated synthesis of highly pure azetidines in aqueous media [39]. The reaction proceeds via the cyclization of 3-(ammonio)propyl sulfates derived from the cyclic sulfate of 1,3-propanediol and primary amines (Scheme 23).

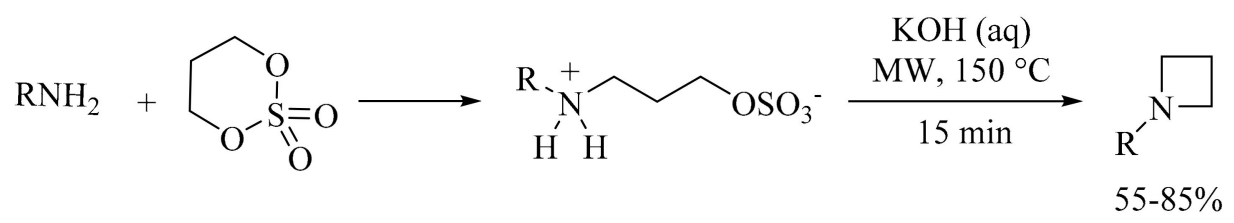

Scheme 23. Microwave-assisted synthesis of azetidines in aqueous media.

Under solvent free conditions, the terminal alkynes, carbodiimides and sulfonyl azides reacts efficiently to generate $N$-Sulfonylazetidin-2-imines [40]. This one-pot three component reaction is catalyzed by an eco-friendly copper(I) oxide catalyst without the support of any ligand or base. The azetidin-2-ylidene derivatives have also been successfully prepared when 1,2-diamine were used as nucleophiles (Scheme 24).

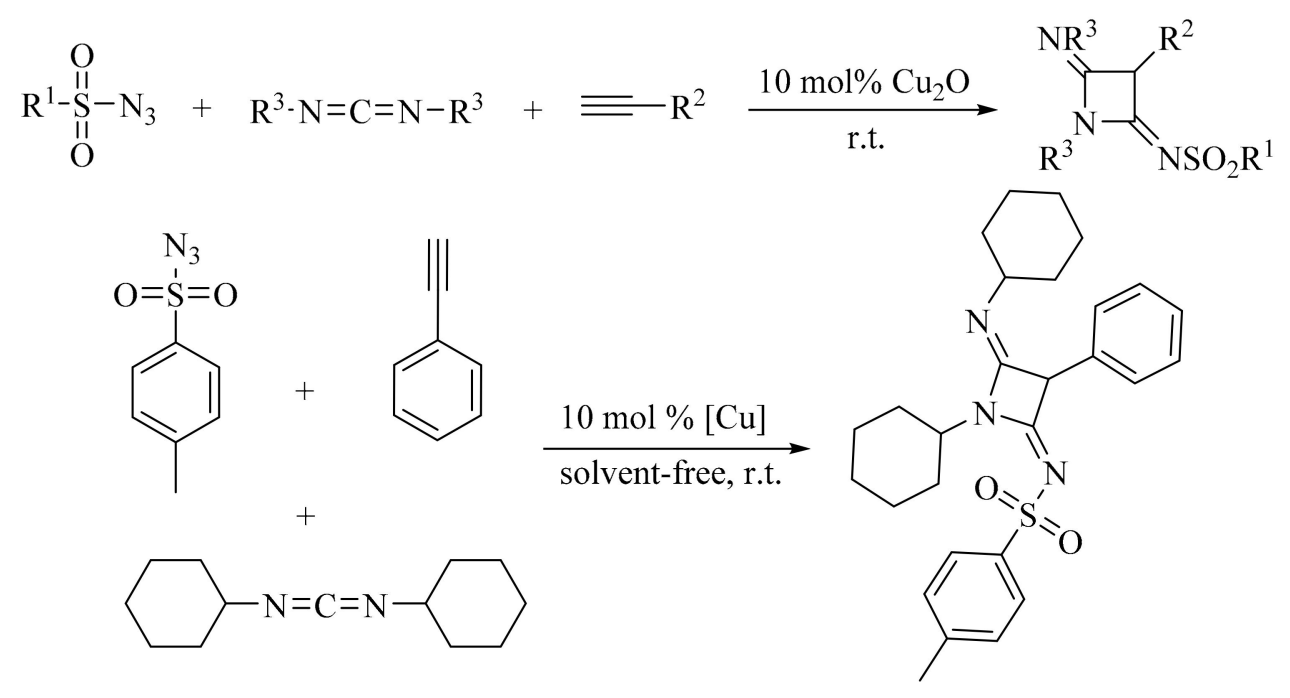

Scheme 24. Synthesis of N-Sulfonylazetidin-2-imines.

\section{Green Synthesis of Pyrrolidines}

$\mathrm{Xu}$ and his co-workers came up with a simple, efficient and one-pot procedure for the synthesis of cyclic amines. The reaction proceeds with the chlorination of amino alcohols and subsequently results in the formation of cyclic amines (Scheme 25). Here, the chlorination step obviates the use of common N-protection/O-activation/cyclization/deprotection steps required for such transformations. The scope of the reaction has been well-explored and the mechanistic aspects were studied in detail [41]. 


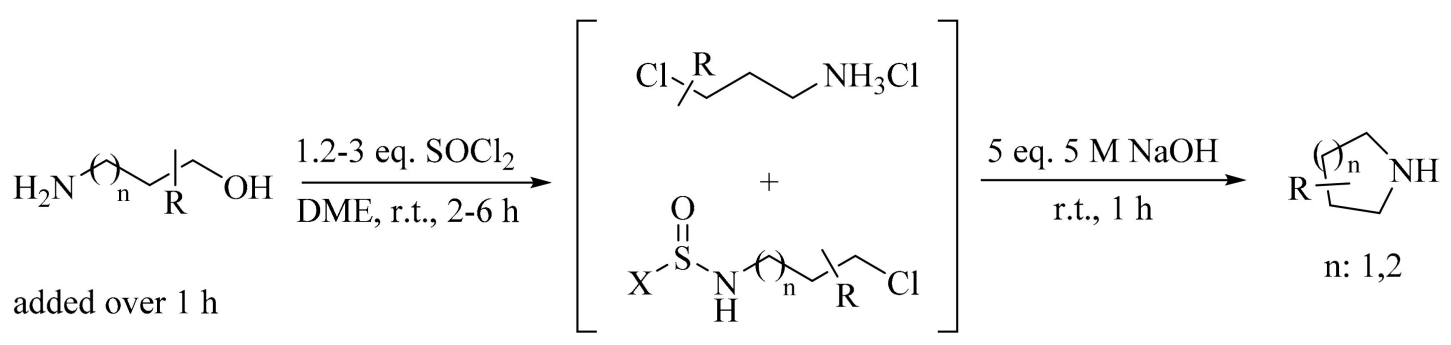

$\mathrm{X}: \mathrm{Cl}, \mathrm{OH}$

Scheme 25. One-pot synthesis of cyclic amines.

Jain and his colleagues reported a simple one-pot three-component reaction for an easy access to dispiropyrrolidine-bisoxindole derivatives. The reaction involves the cycloaddition trappings of azomethine ylides produced in situ through decarboxylative condensation of isatin with sarcosine (Scheme 26). This environmentally benign, operationally simple, highly regio- and stereoselective reaction completes in short time in ionic liquid solvent without the requirement of any catalyst [42].

Zhang et al. presented a one-pot highly enantioselective methodology for the synthesis of cyclic amines including pyrrolidine, piperidine and azocane via intramolecular reductive amination of $\mathrm{N}$-Boc-protected aminoketones (Scheme 27) [43].

Abdulrahman et al. also reported the synthesis of dispirooxindolo-pyrrolidines in good yields with high regioselectivities. The one-pot three component 1,3-dipolar cycloaddition methodology involves the reaction between in situ generated azomethine ylides from L-phenylalanine with substituted isatin with unusual (E)-2-oxoindolino-3-ylidene acetophenone dipolarophiles (Scheme 28). The reaction is run in recyclable ionic liquids [44].

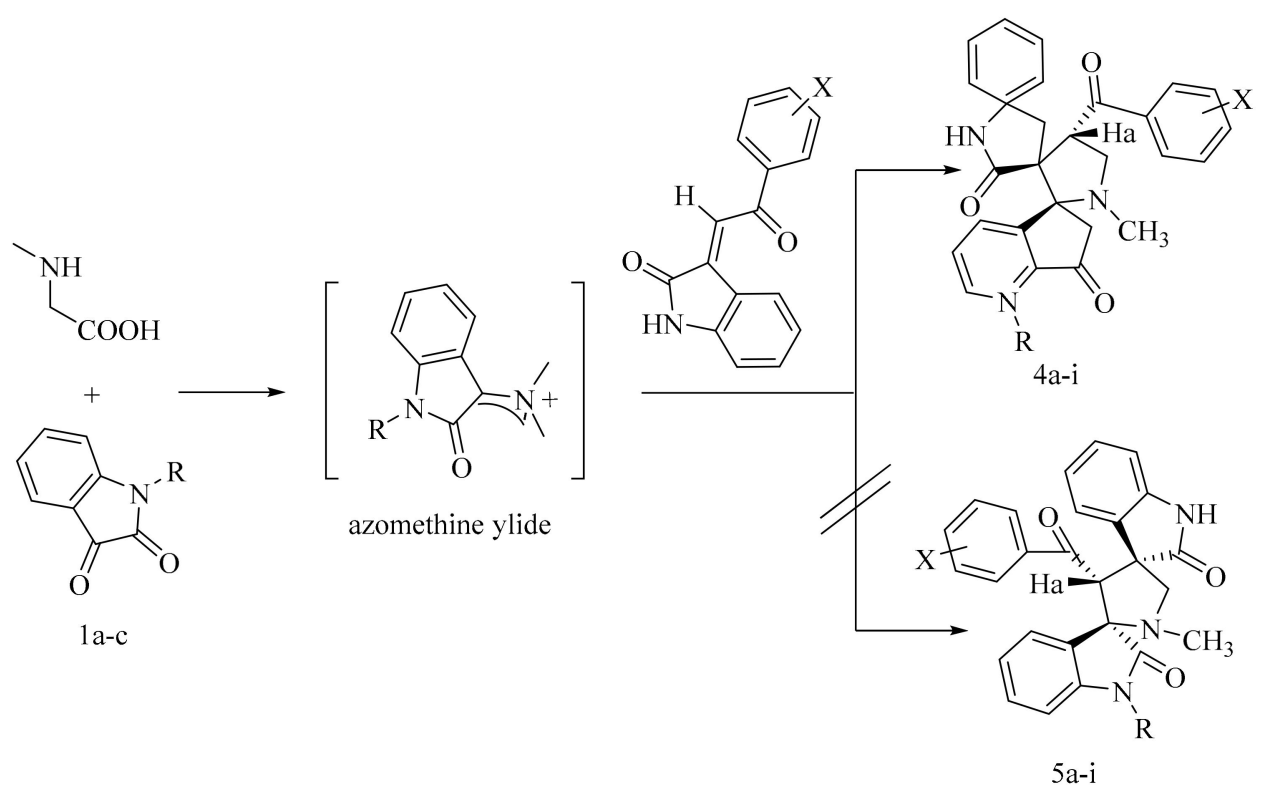

Scheme 26. One-pot synthesis of dispiropyrrolidine-bisoxindole derivatives. 


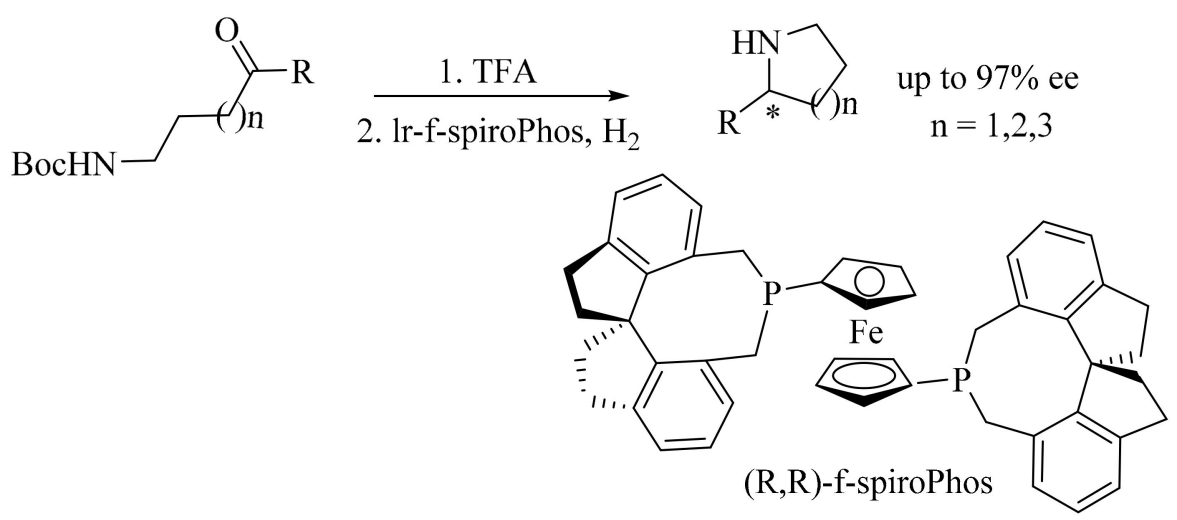

Scheme 27. Synthesis of cyclic amines from $N$-Boc protected amino ketones.
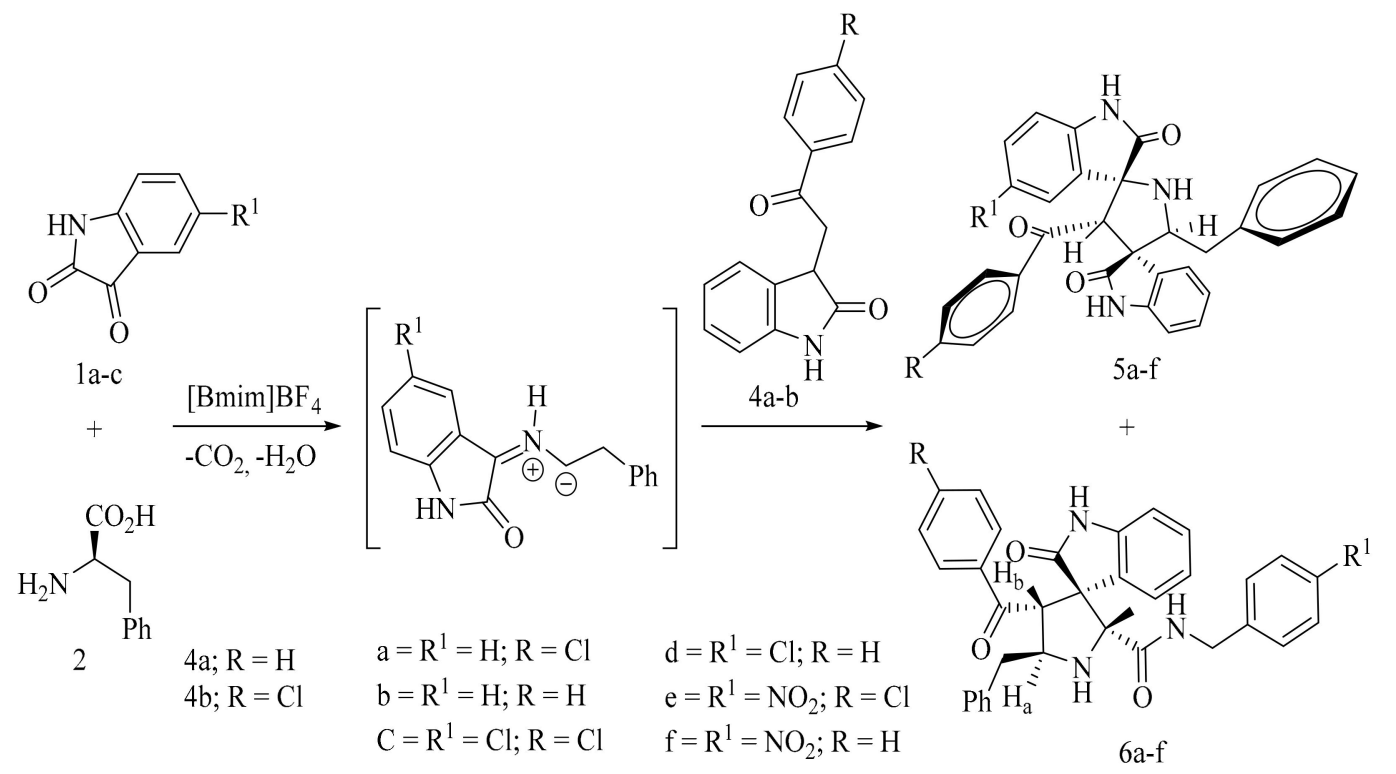

Scheme 28. One-pot synthesis of dispirooxindolo-pyrrolidines.

Ugarriza et al. presented an excellent methodology for the synthesis of C3-unsubstituted pyrrolidines with about $80 \%$ enantiomeric control and complete diastereomeric control. The in situ formed acyclic azomethine ylides react with acrolein through [3+2]-cycloadditions to furnish high yields of the product (Scheme 29). The reaction was catalyzed by easily available chiral amines like L-proline [45].<smiles>[R]C=NC(C#N)C(=O)OCC</smiles>

$\mathrm{R}^{1}=$ Aryl, alkenyl

$\mathrm{R}^{2}=$ Aryl, Alkyl

$\mathrm{EWG}=\mathrm{CO}_{2} \mathrm{Me}, \mathrm{CO}_{2} \mathrm{Et}, \mathrm{CN}$<smiles>[R]C1N[C@]([Y10])(OCC)[C@@H]([R])[C@H]1C=O</smiles>

Yield: $57-97 \%$

single diastereoisomer

e.e.: $89-99 \%$

Scheme 29. Synthesis of substituted-pyrrolidines. 
Varma and his research colleagues developed a one-pot methodology for a convenient synthesis of 2-hydroxy pyrrolidines under mild reaction conditions [46]. In the presence of $\mathrm{CeCl}_{3} \cdot 7 \mathrm{H}_{2} \mathrm{O}$ as catalyst, different 2-aminothiazoles or thiadiazoles and 2,3-dihydrofuran reacts to furnish 2-hydroxypyrrolidines (Scheme 30).

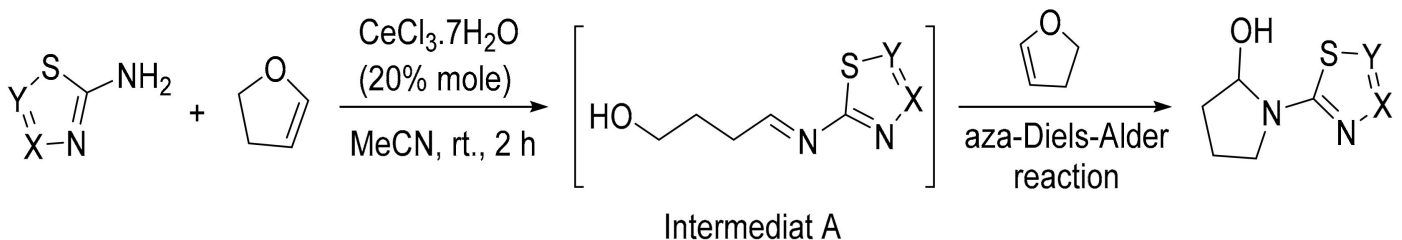<smiles></smiles>

Scheme 30. One-pot synthesis of 2-hydroxypyrrolidines.

Cui and his research team reported a one-pot methodology for enantioselective synthesis of chiral 2-aryl pyrrolidines and piperidines. Under neutral reaction conditions, rhodium hydroxide complex in the presence of chiral bicyclo[3.3.0]octadiene ligands catalyzes arylation of aliphatic $N$-tosylaldimines (Scheme 31). This high yielding method has been adopted for enantioselective synthesis of chiral 2-aryl pyrrolidines and piperidines [47].<smiles>NCCN=CCCCCl</smiles>

2 eq. $\mathrm{B}(\mathrm{OH})_{2}-\mathrm{Ar}$
1) $1.5 \mathrm{~mol}-\%\left[\mathrm{Rh}(\mathrm{OH})(\text { ligand }]_{2}\right.$ dioxane, $\mathrm{MS} 4 \mathrm{~A}^{\circ}, 70^{\circ} \mathrm{C}, 6 \mathrm{~h}$

2) 5 eq. $\mathrm{K}_{2} \mathrm{CO}_{3}$ dioxane/ $\mathrm{H}_{2} \mathrm{O} / \mathrm{DMF}(2: 1: 1)$ r.t. $(\mathrm{n}=1)$ or $70^{\circ} \mathrm{C}(\mathrm{n}=2), 2 \mathrm{~h}$ ligand<smiles></smiles><smiles>C1=C(c2ccccc2)C2CC=C(c3ccccc3)C2C1</smiles>

Scheme 31. Synthesis of chiral 2-aryl pyrrolidines and piperidines.

In 2002, Gandon and Szymoniak reported an excellent procedure to access bifunctional nitrogen-heterocycles such as 1-azaspirocyclic $\gamma$-lactams, azetidines and pyrrolidines [48]. Imines react with $\mathrm{EtMgCl}$ under $\mathrm{Zr}$-catalyzed reaction conditions to furnish $\mathrm{C}, \mathrm{N}$-dimagnesiated compounds which could be trapped with electrophiles leading to aforementioned N-heterocycles (Scheme 32).

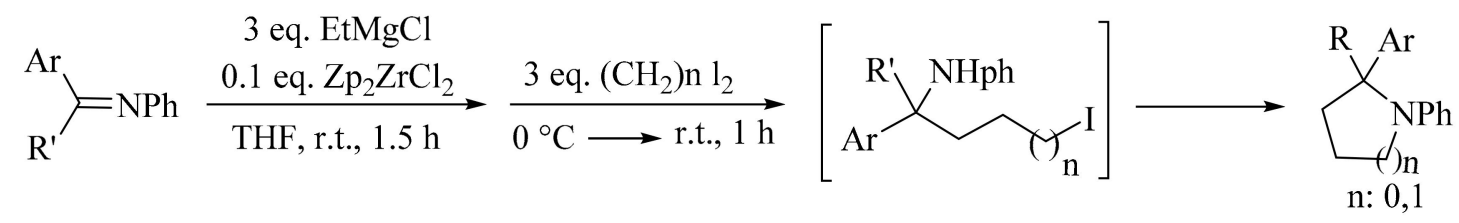

Scheme 32. Synthesis of bifunctional cyclic amines.

In 2006, de Figueiredo and his colleagues described an efficient method for the synthesis of functionalized $p$-methoxyphenyl-protected 4-, 5- and 6-membered $N$-heterocycles (Scheme 33). 
This strategy involves the activation of hydroxyl group of amino alcohol without the use of toxic reagents. The scope of the reaction has been well-established by its ability to tolerate various functional groups [49].<smiles>OCCC[C@H](N=[InH])[C@H](CCO)CO[18OH]</smiles>

1) 3.3 eq. $\mathrm{CDl}$

MeCN, reflux, 2 h

2) removal of volatiles

3) $\mathrm{THF} / 2 \mathrm{~N} \mathrm{NaOH}(1: 1)$ r.t., $2 \mathrm{~h}$<smiles></smiles>

$69 \%$

Scheme 33. Synthesis of functionalized $p$-methoxyphenyl-protected 4-, 5- and 6-membered $N$-heterocycles.

Carson and his colleagues presented an excellent one-pot three-component procedure for the synthesis of substituted pyrrolidines [50]. During this reaction, the condensation of anilines or primary amines with aldehydes generates aldimines in situ which subsequently react with 1,1-cyclopropandiesters to afford pyrrolidines (Scheme 34). This high yielding-reaction is catalyzed by $\mathrm{Yb}(\mathrm{OTf})_{3}$.

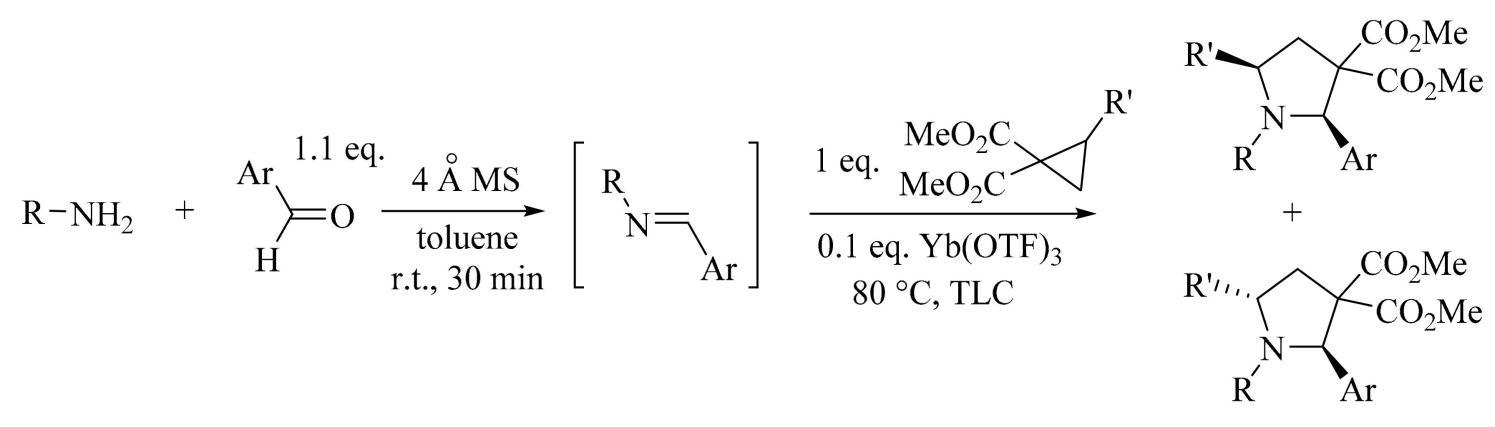

Cis/trans $\sim 4: 1$

Scheme 34. Synthesis of substituted pyrrolidines.

Nayak and her research group described an operationally simple, eco-friendly and novel one-pot three component reaction for the synthesis of spirooxidindole-pyrrolidine/piperidine fused nitrochromanes in good to excellent yields (Scheme 35). The less demanding reaction procedure involves the cycloaddition of isatin-based azomethine ylide and substituted nitrochromenes in nontoxic solvent in shorter time [51].<smiles>O=C1Nc2ccccc2C1=O</smiles>

Scheme 35. Synthesis of spirooxidindole-pyrrolidine/piperidine fused nitrochromanes.

Trost and his colleagues described that aminopropargyl alcohols undergo domino redox isomerization/cyclization to furnish nitrogen heterocycles [52]. In this ruthenium-catalyzed, atom-economical single step reaction a variety of functional groups were tolerated, establishing the broad scope of reaction (Scheme 36). 

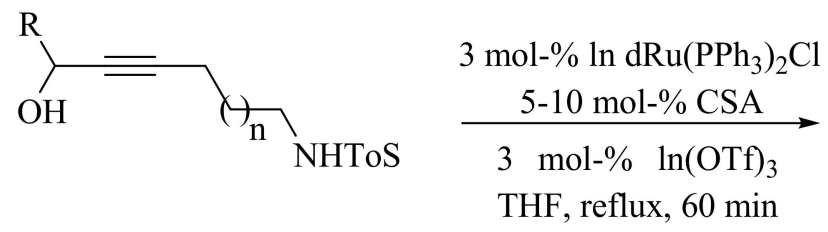

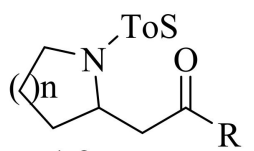

$\mathrm{n}: 1,2$

R: H, alkyl

CSA: Camphor sulfonic acid

Scheme 36. Domino synthesis of cyclic amines.

Methylenecyclopropanes react with sulfonamides through a gold(I)-catalyzed domino ring-opening ring-closing hydroamination process to afford pyrrolidine derivatives in excellent yield (Scheme 37) [53].

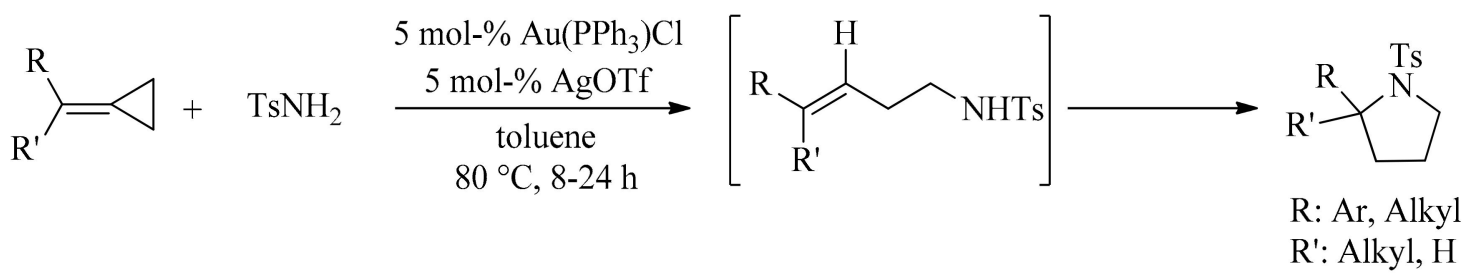

Scheme 37. Gold(I)-catalyzed synthesis of pyrrolidine derivatives.

Multisubstituted pyrrolidines were made accessible with high diastereoselectivity by the tandem ring-opening-cyclization reaction of imines with cyclopropanes (Scheme 38). Kang and his research team used $5 \mathrm{~mol} \%$ of scandium triflate as catalyst for the reaction [54].

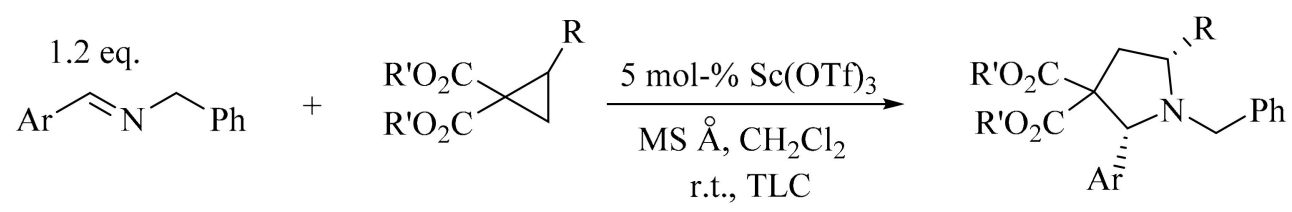

Scheme 38. Synthesis of multisubstituted pyrrolidines by tandom reaction.

Nguyen and Nicewicz presented a metal-free procedure for the synthesis of nitrogen-containing heterocyles with complete regiocontrol. The reaction involves a direct anti-Markonikov hydroamination of unsaturated amines (Scheme 39). In the presence of 9-mesityl-10-methylacridinium tetrafluoroborate as catalyst, the substrate amines are irradiated with visible light and thiophenol manages to donate H-atom [55].

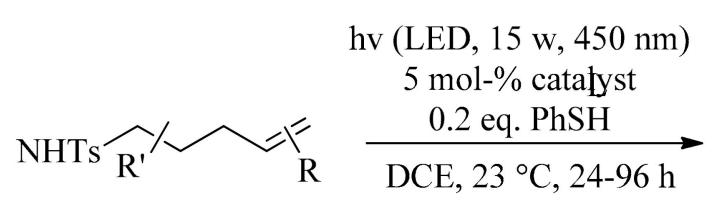<smiles>[R]C1CCCN1[13CH]</smiles><smiles></smiles>

Scheme 39. Metal-free synthesis of nitrogen-containing heterocyles.

Enones and unsaturated carbamates undergo a tandem cross-metathesis intramolecular aza-Michael reaction to generate $\beta$-amino carbonyl compounds (Scheme 40). The reaction is efficiently promoted by a combination of $\mathrm{BF}_{3} \cdot \mathrm{OEt}_{2}$ and Hoveyda-Grubbs catalyst. In this reaction, a dramatic 
acceleration is observed under microwave irradiation with inversion of stereoselectivity in the addition step [56].

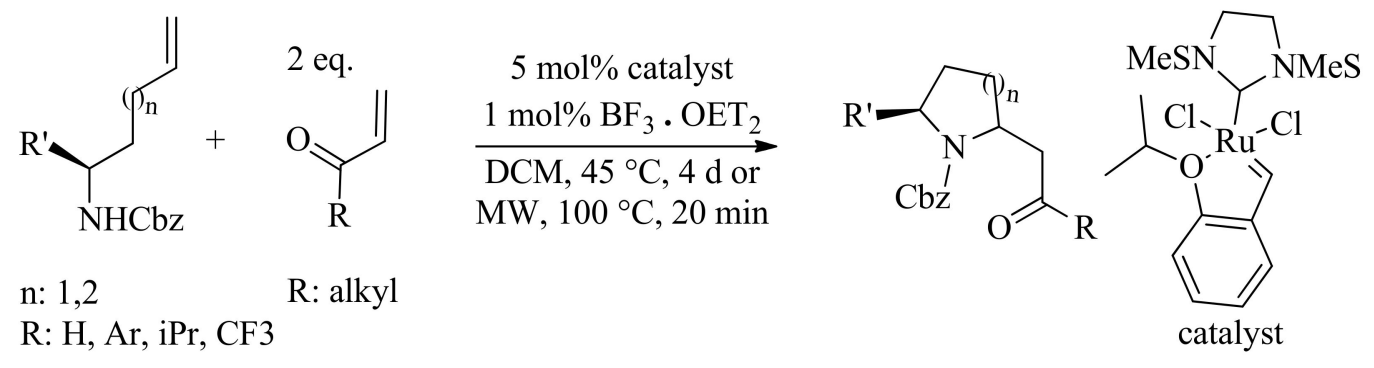

Scheme 40. Microwave assisted synthesis of pyrrolidines.

A highly endo-selective asymmetric 1,3-dipolar cycloaddition reaction of methyl $\mathrm{N}$-benzylideneglycinate as source of azomethine ylides with $(E)$-acyclic $\alpha$-enones is catalyzed by a silver(I)/ThioClickFerrophos complex to give highly functionalized endo-4-acyl pyrrolidines in good yields with high enantioselectivities (Scheme 41) [57].<smiles>CC(=O)CN=C[Te]</smiles>

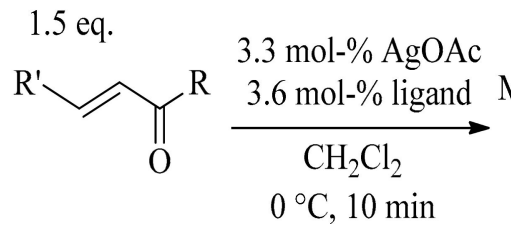

R: Ar, Me, venyl
$0{ }^{\circ} \mathrm{C}, 10 \mathrm{~min}$

R': Ar, Me

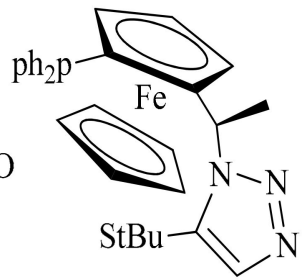

ligand

Scheme 41. Synthesis of highly functionalized endo-4-acyl pyrrolidines.

\section{Green Synthesis of Piperidines}

Bansal et al. developed one-pot multicomponent reaction to access highly functionalized piperidines in moderate to good yields (Scheme 42). The reaction involves the condensation of amines, aldehydes and $\beta$-ketoesters catalyzed by a recyclable, nontoxic, and eco-friendly sodium lauryl sulfate. As an advantage, the reaction completes in water at room temperature and requires simple workup to furnish highly substituted piperidines [58].
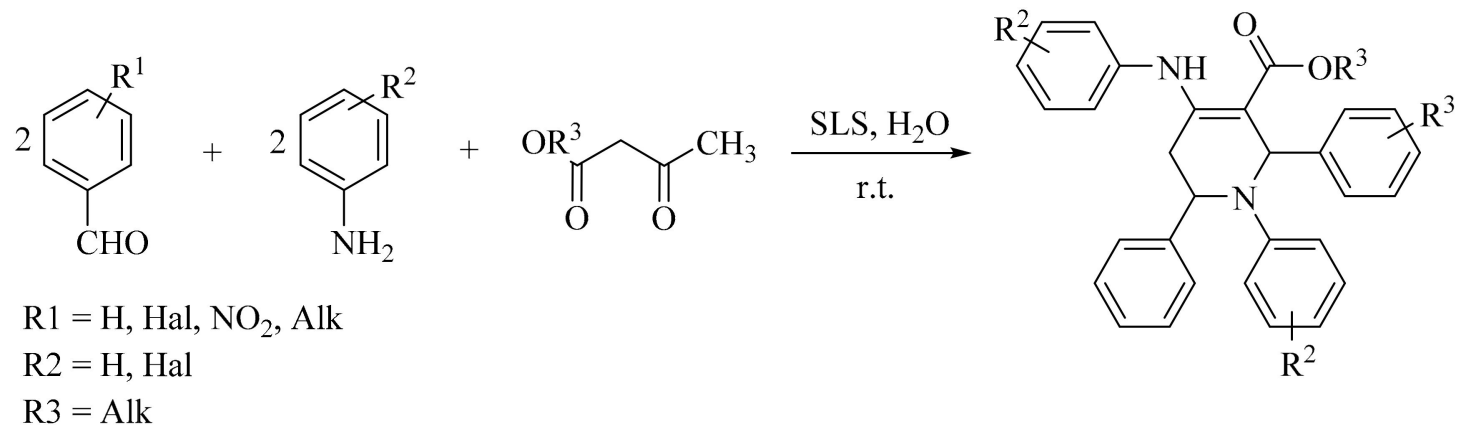

Scheme 42. One-pot multicomponent synthesis of highly functionalized piperidines.

The abovementioned reaction (Scheme 42) had also been studied by Khan et al. for the highly functionalized piperidine as well for fully substituted piperidines (Scheme 43). The described one-pot multicomponent procedure offered a green approach due to atom economy, mild conditions and good yields [59]. 


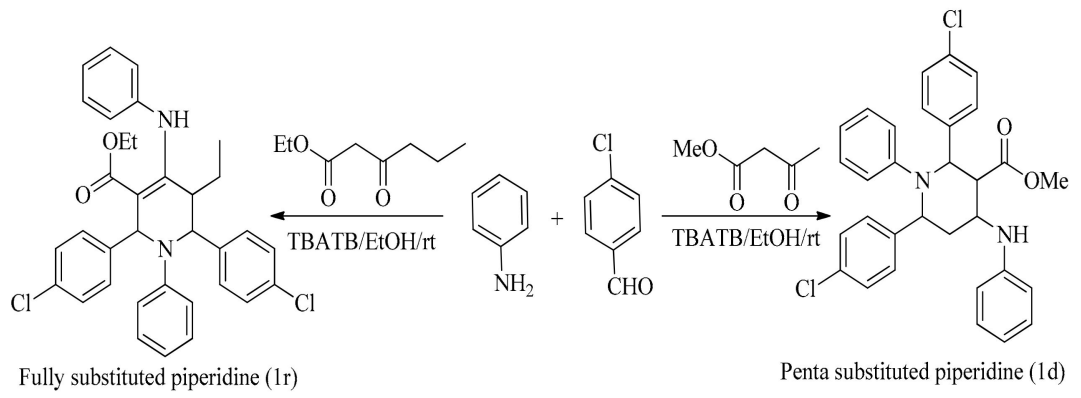

Scheme 43. Synthesis of highly functionalized and fully substituted piperidines.

In 2010, Guérinot et al. represented an eco-friendly methodology for the synthesis cis-2,6-tetrahydropyrans and substituted cis-2,6-piperidines in good to excellent yields (Scheme 44). In this highly diastereoselective iron catalyzed reaction, the most stable cis-isomers are easy to isolate and purify [60].<smiles>[R]C([Y1])/C=C/CCCC([R20])[Y]</smiles>

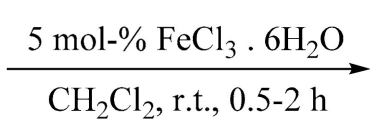<smiles>[Y8]C=C[C@@H]1[CH][C@H]([R])CCC1</smiles>

¡: NTs R": alkyl, Ph, H

Scheme 44. Synthesis of substituted cis-2,6-piperidines.

LaLonde and his co-workers described phosphinegold(I)-bis-p-nitrobenzoate complex catalyzed intramolecular hydroamination of alkenes to access vinyl pyrrolidines and piperidines (Scheme 45). This atom-economical and enantioselective reaction results in high ee [61].

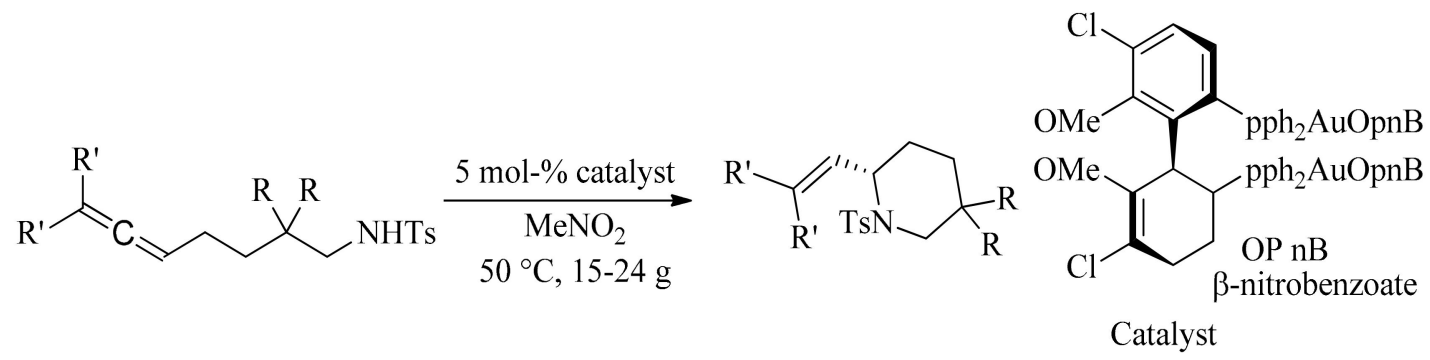

Scheme 45. Synthesis of vinyl piperidines.

Métro and his research colleagues presented a high-yielding microwave-assisted reaction for the enantioselective synthesis of piperidines (Scheme 46) [62].

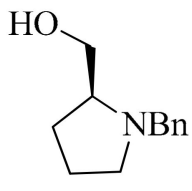

$$
\begin{aligned}
& \text { 1) } 0.2 \text { eq. TFAA, THF } \\
& \mathrm{MW}, 180^{\circ} \mathrm{C}, 2 \mathrm{~h} \\
& \underset{\text { 2) } 0.3 \text { eq. } \mathrm{NaOH}}{(3.75 \mathrm{M} \text { aq.), r.t., } 2 \mathrm{~h}}
\end{aligned}
$$

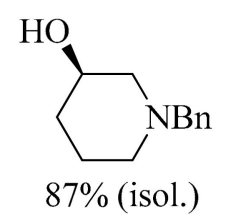

Scheme 46. Microwave-assisted enantioselective synthesis of piperidines.

Maegawa and his fellows presented an excellent methodology for mild and complete hydrogenation of various carbon and heteroatomic compounds including furans, biphenyls, pyridines, 
alkylbenzenes, etc. [63]. The same reaction has been adopted for the synthesis of piperidines in good to excellent yield in aqueous media (Scheme 47).

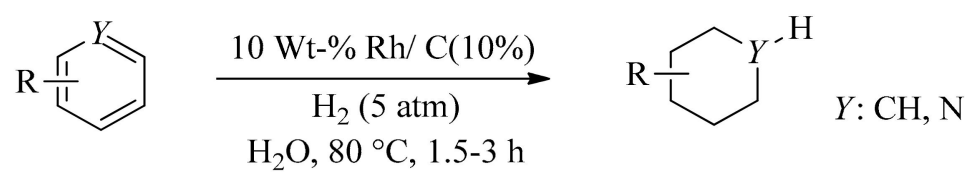

Scheme 47. Synthesis of piperidines in aquous media.

\section{Green Synthesis of Azepanes}

Valle and his colleague reported a one-pot synthesis of polyhydroxylated aminoazepanes using $\mathrm{Ph}_{3} \mathrm{P}$ in aqueous solvent. In the reaction, the D-glucitol was initially converted into 1,6-diazido derivatives which subsequently got converted into the product (Scheme 48) [64].
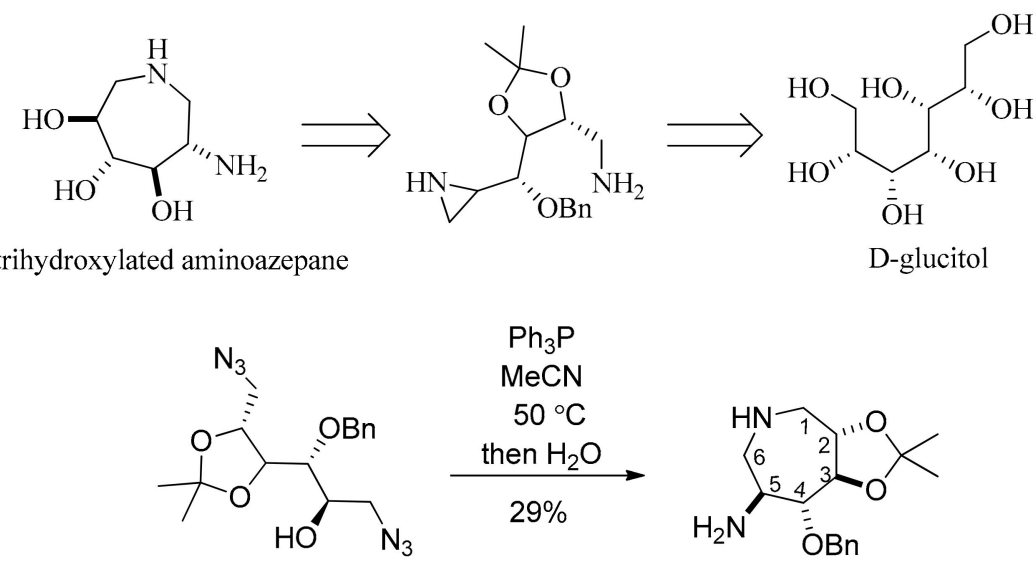

Scheme 48. Synthesis of polyhydroxylated azopanes.

Calder et al. presented a one-pot multi-reaction strategy for the synthesis of hydroxylated 3-aminoazepanes (Scheme 49) [65].

Wishka and his colleagues presented a successful method for the synthesis of $(2 S, 5 S)$-5-substituted-azepane-2-carboxylate derivatives starting from known hydroxyl ketone (Scheme 50) [66].

Zhang and his co-workers described the alkylation of amines with alcohol for the synthesis of cyclic amines (Scheme 51). This microwave assisted iridium catalyzed reaction recognized as a green reaction because of its features like atom-economy, solvent-free and base-free conditions [67].

Further, the green and facile methods including one-pot, domino and microwave assisted reactions for the synthesis of azopane has already been described in Schemes 28, 30, 34, 39 and 43. 
<smiles>C=CCCN(CC=CCO)C(=O)OCc1ccccc1</smiles>

1. $\mathrm{Cl}_{3} \mathrm{CCN}$

$\underset{\text { 2. } \mathrm{PdCl}_{2}(\mathrm{MeCN})_{2}}{\stackrel{\mathrm{DBU} \text { (cat. })}{\longrightarrow}}$

3. Grubbs II,

$79 \%$ yield over three steps

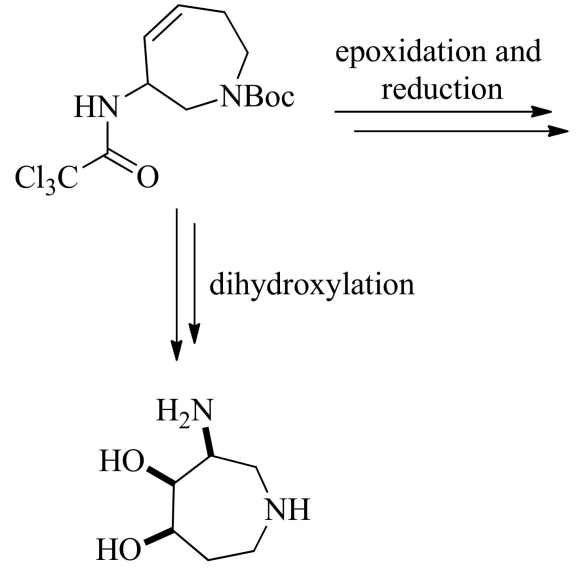

Scheme 49. Synthesis of hydroxylated 3-aminoazepanes.<smiles>[R]C[C@@H]1CCC(CCS)=C(C(=O)OC)N(C(=O)OC[R](C)C)CC1</smiles>

Scheme 50. Synthesis of (2S,5S)-5-substituted-azepane-2-carboxylate derivatives.

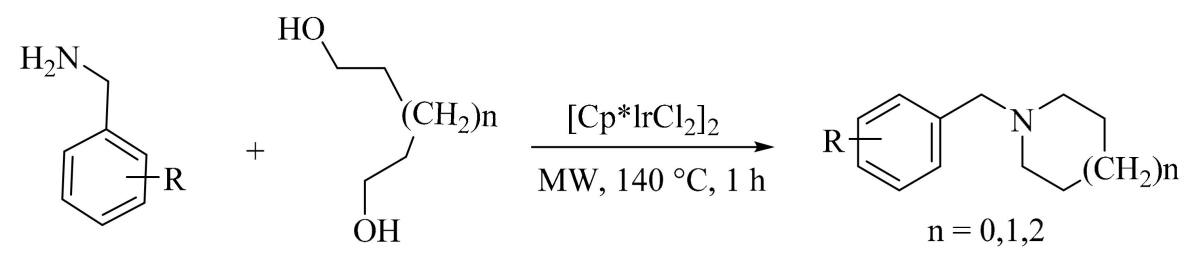

Scheme 51. Microwave assisted iridium catalyzed synthesis of cyclic amines.

\section{Green Synthesis of Azocanes}

Sacher and his fellow developed following atom economical methodology for the construction of the azocane ring (Scheme 52) [68].
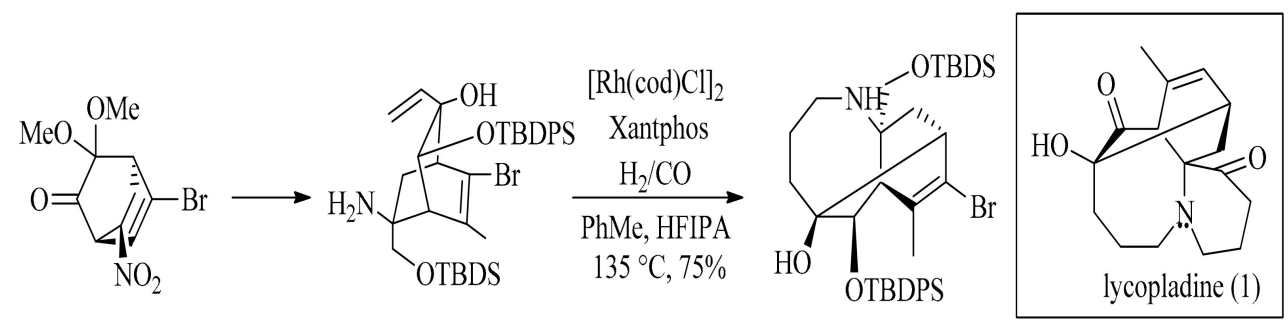

Scheme 52. Atom economical synthesis of azocane. 
The green synthesis of azocanes has also been described in Schemes 27 and 31.

\section{Conclusions}

In conclusion, the presence of saturated cyclic amines in a number of naturally occurring bioactive molecules and in synthetic drugs has indicated their various potential roles in the past few decades. Further, vast arrays of applications in various scientific disciplines have triggered the development of new methods for their facile synthesis. This manuscript has highlighted some eco-friendly and facile synthetic routes for the synthesis of unsubstituted, fully substituted and functionalized aziridines, azetidines, pyrrolidines, piperidines, azepanes and azocanes.

Author Contributions: A.H. discussion and writing. S.J. review of literature. R.N. coordination and discussion. T.H. discussion and chem-drawing. S.I. discussion and literature review. H.U. discussion and manuscript out-lining. T.G. discussion and proof reading. T.F. literature review, write-up and supervision.

Conflicts of Interest: The authors declare no conflict of interests.

\section{References}

1. Bouyssi, D.; Monteiro, N.; Balme, G. Amines as key building blocks in Pd-assisted multicomponent processes. Beilstein J. Org. Chem. 2011, 7, 1387-1406. [CrossRef] [PubMed]

2. Goethals, E.J.; Schacht, E.H.; Bruggeman, P.; Bossaer, P. Cationic Polymerization of Cyclic Amines. In Ring-Opening Polymerization; American Chemical Society: Washington, DC, USA, 1977; Volume 59, pp. 1-12.

3. Noshadi, I.; Kanjilal, B.; Jafari, T.; Moharreri, E.; Khakpash, N.; Jiang, T.; Suib, S.L. Hydrophobic mesoporous adsorbent based on cyclic amine-divinylbenzene copolymer for highly efficient siloxane removal. RSC Adv. 2016, 6, 77310-77320. [CrossRef]

4. Hunger, K. Industrial Dyes: Chemistry, Properties, Applications; Wiley: Kelkhem, Germany, 2007.

5. Wu, T.Y.; Su, S.G.; Gung, S.T.; Lin, M.W.; Lin, Y.C.; Ou-Yang, W.C.; Sun, I.W.; Lai, C.A. Synthesis and characterization of protic ionic liquids containing cyclic amine cations and tetrafluoroborate anion. J. Iran. Chem. Soc. 2011, 8, 149-165. [CrossRef]

6. Hall, H.K. Steric Effects on the base strengths of cyclic amines1. J. Am. Chem. Soc. 1957, 79, 5444-5447. [CrossRef]

7. Shi, Y.; Chu, W.; Wang, Y.; Wang, S.; Du, J.; Zhang, J.; Li, S.; Zhou, G.; Qin, X.; Zhang, C. Synthesis, characterization and cytotoxicity of the $\mathrm{Au}(\mathrm{III})$ complexes with cyclic amine-based dithiocarbamate ligands. Inorg. Chem. Commun. 2013, 30, 178-181. [CrossRef]

8. Zhang, X. Transition Metal-Catalyzed Reactions Based on Chiral Amine Oxazolinyl Ligands. U.S. Patent 6,255,493, 3 July 2001.

9. Taylor, R.D.; MacCoss, M.; Lawson, A.D.G. Rings in drugs. J. Med. Chem. 2014, 57, 5845-5859. [CrossRef] [PubMed]

10. Ismail, F.M.; Levitsky, D.O.; Dembitsky, V.M. Aziridine alkaloids as potential therapeutic agents. Eur. J. Med. Chem. 2009, 44, 3373-3387. [CrossRef] [PubMed]

11. Shiota, T.; Kataoka, K.-I.; Imai, M.; Tsutsumi, T.; Sudoh, M.; Sogawa, R.; Morita, T.; Hada, T.; Muroga, Y.; Takenouchi, O. Cyclic Amine Derivatives and Their Use as Drugs. WO 1999025686 A1, 27 May 1999.

12. Urch, C.J.; Salmon, R.; Lewis, T.; Godfrey, C.R.A.; Clough, M.S. Bicyclic Amines as Insecticides. WO 1996037494 A1, 28 November 1996.

13. Zambach, W.; Hueter, O.F.; Wenger, J.; Goeghova, M.; Pitterna, T.; Maienfisch, P.; Muehlebach, M. Spiroheterocyclic Pyrrolidine Dione Derivatives Useful as Pesticides. WO 2009049851 A1, 23 April 2009.

14. Duke, S.O.; Cantrell, C.L.; Meepagala, K.M.; Wedge, D.E.; Tabanca, N.; Schrader, K.K. Natural toxins for use in pest management. Toxins 2010, 2, 1943-1962. [CrossRef] [PubMed]

15. Fokas, D.; Coffen, D.L.; Ryan, W.J. Spiro [Pyrrolidine-2,3'-oxindole] Compounds and Methods of Use. WO 1999012904 A1, 8 March 1999.

16. Wan, X.W.; Peng, Y.Q.; Gan, H.J.; Shi, Z.L.; Xing, G. Mixed Weedicide as Well as Preparation Method and Application Thereof. CN 104351234 A, 18 February 2015. 
17. Turner, N.J.; Truppo, M.D. Biocatalytic routes to nonracemic chiral amines. In Chiral Amine Synthesis; Wiley-VCH: Weinheim, Germany, 2010.

18. Kohls, H.; Steffen, M.F.; Hohne, M. Recent achievements in developing the biocatalytic toolbox for chiral amine synthesis. Curr. Opin. Chem. Biol. 2014, 19, 180-192. [CrossRef] [PubMed]

19. Nugent, T.C. Chiral Amine Synthesis: Methods, Developments and Applications; John Wiley \& Sons: Bremen, Germany, 2010.

20. Bieber, L.; De Araújo, M. Short and efficient synthesis of optically active $N$-tosyl aziridines from 2-amino alcohols. Molecules 2002, 7, 902-906. [CrossRef]

21. Lohray, B.B.; Gao, Y.; Sharpless, K.B. One pot synthesis of homochiral aziridines and aminoalcohols from homochiral 1,2-cyclic sulfates. Tetrahedron Lett. 1989, 30, 2623-2626. [CrossRef]

22. Hayashi, Y.; Urushima, T.; Sakamoto, D.; Torii, K.; Ishikawa, H. One-pot synthesis of chiral aziridines by a domino reaction by using desulfonylative formation on the $N$-tosyl imine of chloroacetaldehyde with an asymmetric mannich reaction as a key step. Chem. Eur. J. 2011, 17, 11715-11718. [CrossRef] [PubMed]

23. Groeper, J.A.; Eagles, J.B.; Hitchcock, S.R. A facile, one-pot synthesis of Ephedra-based aziridines. Tetrahedron Asymmetry 2009, 20, 1969-1974. [CrossRef]

24. Yadav, L.D.S.; Kapoor, R. Organocatalytic stereoselective aziridination of imines via ammonium ylides. Synlett 2009, 2009, 3123-3126. [CrossRef]

25. Fadeyi, O.O.; Schulte, M.L.; Lindsley, C.W. General access to chiral N-alkyl terminal aziridines via organocatalysis. Org. Lett 2010, 12, 3276-3278. [CrossRef] [PubMed]

26. Kim, H.Y.; Talukdar, A.; Cushman, M. Regioselective synthesis of $N$ - $\beta$-hydroxyethylaziridines by the ring-opening reaction of epoxides with aziridine generated in situ. Org. Lett. 2006, 8, 1085-1087. [CrossRef] [PubMed]

27. Kano, D.; Minakata, S.; Komatsu, M. Novel organic-solvent-free aziridination of olefins: Chloramine-T- $\mathrm{I}_{2}$ system under phase-transfer catalysis conditions. J. Chem. Soc. Perkin Trans. 1 2001, 23, 3186-3188. [CrossRef]

28. Kiyokawa, K.; Kosaka, T.; Minakata, S. Metal-free aziridination of styrene derivatives with iminoiodinane catalyzed by a combination of iodine and ammonium iodide. Org. Lett. 2013, 15, 4858-4861. [CrossRef] [PubMed]

29. Borkin, D.; Carlson, A.; Török, B. K-10-catalyzed highly diastereoselective synthesis of aziridines. Synlett 2010, 2010, 745-748.

30. Quinodoz, P.; Drouillat, B.; Wright, K.; Marrot, J.; Couty, F. N-Arylazetidines: Preparation through anionic ring closure. J. Org. Chem. 2016, 81, 2899-2910. [CrossRef] [PubMed]

31. Kern, N.; Felten, A.-S.; Weibel, J.-M.; Pale, P.; Blanc, A. Robust synthesis of N-sulfonylazetidine building blocks via ring contraction of $\alpha$-bromo $N$-sulfonylpyrrolidinones. Org. Lett. 2014, 16, 6104-6107. [CrossRef] [PubMed]

32. Malik, S.; Nadir, U.K. A facile synthesis of 1-arenesulfonylazetidines through reaction of 1-arenesulfonylaziridines with dimethylsulfoxonium methylide generated under microwave irradiation. Synlett 2008, 2008, 108-110. [CrossRef]

33. Ju, Y.; Varma, R.S. Aqueous $N$-heterocyclization of primary amines and hydrazines with dihalides: microwave-assisted syntheses of $N$-azacycloalkanes, isoindole, pyrazole, pyrazolidine, and phthalazine derivatives. J. Org. Chem. 2006, 71, 135-141. [CrossRef] [PubMed]

34. Xu, X.; Cheng, D.; Li, J.; Guo, H.; Yan, J. Copper-catalyzed highly efficient multicomponent reactions: Synthesis of 2-(sulfonylimino)-4-(alkylimino)azetidine derivatives. Org. Lett. 2007, 9, 1585-1587. [CrossRef] [PubMed]

35. Hillier, M.C.; Chen, C.Y. A one-pot preparation of 1,3-disubstituted azetidines. J. Org. Chem. 2006, 71, 7885-7887. [CrossRef] [PubMed]

36. Chavan, S.S.; Supekar, M.V.; Burate, P.A.; Rupanwar, B.D.; Shelke, A.M.; Suryavanshi, G. An efficient Sn(ii)-catalyzed one-pot synthesis of a 3-substituted azetidine-2,4-dione framework. Org. Biomol. Chem. 2017, 15, 2385-2391. [CrossRef] [PubMed]

37. Orr, S.T.M.; Cabral, S.; Fernando, D.P.; Makowski, T. One-pot synthesis of chiral azetidines from chloroaldehyde and chiral amines. Tetrahedron Lett. 2011, 52, 3618-3620.

38. Franck, X.; Leleu, S.; Outurquin, F. Regioselective synthesis of azetidines or pyrrolidines by selenium-induced cyclization of secondary homoallylic amines. Tetrahedron Lett. 2010, 51, 4437-4440. [CrossRef] 
39. Burkett, B.A.; Ting, S.Z.; Gan, G.C.S.; Chai, C.L.L. Microwave-assisted synthesis of azetidines in aqueous media. Tetrahedron Lett. 2009, 50, 6590-6592. [CrossRef]

40. Yi, X.; Barry, B.-D.; Liao, P.; Bi, X. Synthesis of N-Sulfonylazetidin-2-imines via the Copper(I) oxide catalyzed multicomponent reaction of alkynes, sulfonyl azides and diimines under solvent-free conditions. Synthesis 2012, 44, 1323-1328. [CrossRef]

41. Xu, F.; Simmons, B.; Reamer, R.A.; Corley, E.; Murry, J.; Tschaen, D. Chlorination/cyclodehydration of amino alcohols with $\mathrm{SOCl}_{2}$ : An old reaction revisited. J. Org. Chem. 2008, 73, 312-315. [CrossRef] [PubMed]

42. Jain, R.; Sharma, K.; Kumar, D. Ionic liquid mediated 1,3-dipolar cycloaddition of azomethine ylides: A facile and green synthesis of novel dispiro heterocycles. Tetrahedron Lett. 2012, 53, 1993-1997. [CrossRef]

43. Zhang, Y.; Yan, Q.; Zi, G.; Hou, G. Enantioselective direct synthesis of free cyclic amines via intramolecular reductive amination. Org. Lett. 2017, 19, 4215-4218. [CrossRef] [PubMed]

44. Almansour, A.I.; Arumugam, N.; Kumar, R.S.; Periyasami, G.; A. Ghabbour, H.; Fun, H.K. A novel one-pot green synthesis of dispirooxindolo-pyrrolidines via 1,3-dipolar cycloaddition reactions of azomethine ylides. Molecules 2015, 20, 780-791. [CrossRef] [PubMed]

45. Ugarriza, I.; Uria, U.; Reyes, E.; Carrillo, L.; Vicario Jose, L. Organocatalytic enantioselective [3 + 2] cycloaddition of azomethine ylides and acrolein. Asymmetric Catal. 2015, 2, 26-36. [CrossRef]

46. Varma, P.P.; Mahadevan, K.M.; Khader, A.; Hulikal, V. One pot synthesis of 2-hydroxy pyrrolidine derivatives. Org. Commun. 2011, 4, 52.

47. Cui, Z.; Yu, H.-J.; Yang, R.-F.; Gao, W.-Y.; Feng, C.-G.; Lin, G.-Q. Highly enantioselective arylation of $\mathrm{N}$-tosylalkylaldimines catalyzed by rhodium-diene complexes. J. Am. Chem. Soc. 2011, 133, 12394-12397. [CrossRef] [PubMed]

48. Gandon, V.; Bertus, P.; Szymoniak, J. Conversion of imines into C,N-dimagnesiated compounds and trapping with electrophiles. One-pot access to 1-azaspirocyclic framework. Synthesis 2002, 2002, 1115-1120. [CrossRef]

49. De Figueiredo, R.M.; Fröhlich, R.; Christmann, M. N,N'-Carbonyldiimidazole-mediated cyclization of amino alcohols to substituted azetidines and other $N$-heterocycles. J. Org. Chem. 2006, 71, 4147-4154. [CrossRef] [PubMed]

50. Carson, C.A.; Kerr, M.A. Diastereoselective synthesis of pyrrolidines via the Yb (OTf) 3 catalyzed three-component reaction of aldehydes, amines, and 1,1-cyclopropanediesters. J. Org. Chem. 2005, 70, 8242-8244. [CrossRef] [PubMed]

51. Nayak, S.; K. Mishra, S.; Bhakta, S.; Panda, P.; Baral, N.; Mohapatra, S.; S. Purohit, C.; Satha, P. Green synthesis of spirooxindole-pyrrolidine/piperidine fused nitrochromane: One pot three component stereo and regioselective cycloaddition. Lett. Org. Chem. 2016, 13, 11-21. [CrossRef]

52. Trost, B.M.; Maulide, N.; Livingston, R.C. A ruthenium catalyzed, atom-economical synthesis of nitrogen heterocycles. J. Am. Chem. Soc. 2008, 130, 16502-16503. [CrossRef] [PubMed]

53. Shi, M.; Liu, L.-P.; Tang, J. Gold (I)-catalyzed domino ring-opening ring-closing hydroamination of methylenecyclopropanes (MCPs) with sulfonamides: Facile preparation of pyrrolidine derivatives. Org. Lett. 2006, 8, 4043-4046. [CrossRef] [PubMed]

54. Kang, Y.-B.; Tang, Y.; Sun, X.-L. Scandium triflate catalyzed cycloaddition of imines with 1,1-cyclopropanediesters: Efficient and diastereoselective synthesis of multisubstituted pyrrolidines. Org. Biomol. Chem. 2006, 4, 299-301. [CrossRef] [PubMed]

55. Nguyen, T.M.; Nicewicz, D.A. Anti-markovnikov hydroamination of alkenes catalyzed by an organic photoredox system. J. Am. Chem. Soc. 2013, 135, 9588-9591. [CrossRef] [PubMed]

56. Fustero, S.; Jiménez, D.; Sánchez-Roselló, M.; del Pozo, C. Microwave-assisted tandem cross metathesis intramolecular aza-Michael reaction: An easy entry to cyclic $\beta$-amino carbonyl derivatives. J. Am. Chem. Soc. 2007, 129, 6700-6701. [CrossRef] [PubMed]

57. Oura, I.; Shimizu, K.; Ogata, K.; Fukuzawa, S.-I. Highly endo-selective and enantioselective 1,3-dipolar cycloaddition of azomethine ylide with $\alpha$-enones catalyzed by a silver (I)/ThioClickFerrophos complex. Org. Lett. 2010, 12, 1752-1755. [CrossRef] [PubMed]

58. Bansal, R.; Soni, P.; Sharma, J.; Bhardwaj, S.; Halve, A. One-pot multi-component green synthesis of highly substituted piperidines. Curr. Chem. Lett. 2017, 6, 135-142. [CrossRef]

59. Khan, A.T.; Lal, M.; Khan, M.M. Synthesis of highly functionalized piperidines by one-pot multicomponent reaction using tetrabutylammonium tribromide (TBATB). Tetrahedron Lett. 2010, 51, 4419-4424. [CrossRef] 
60. Guérinot, A.; Serra-Muns, A.; Gnamm, C.; Bensoussan, C.; Reymond, S.; Cossy, J. FeCl 3 -catalyzed highly diastereoselective synthesis of substituted piperidines and tetrahydropyrans. Org. lett. 2010, 12, 1808-1811. [CrossRef] [PubMed]

61. LaLonde, R.L.; Sherry, B.D.; Kang, E.J.; Toste, F.D. Gold (I)-catalyzed enantioselective intramolecular hydroamination of allenes. J. Am. Chem. Soc. 2007, 129, 2452-2453. [CrossRef] [PubMed]

62. Métro, T.-X.; Pardo, D.G.; Cossy, J. Highly enantioselective synthesis of $\beta$-amino alcohols: A catalytic version. J. Org. Chem. 2007, 72, 6556-6561. [CrossRef] [PubMed]

63. Maegawa, T.; Akashi, A.; Sajiki, H. A mild and facile method for complete hydrogenation of aromatic nuclei in water. Synlett 2006, 2006, 1440-1442. [CrossRef]

64. Valle, M.S.; Braga, R.M. Synthesis of a trihydroxylated aminoazepane from D-glucitol by an intramolecular aziridine ring opening. Synlett 2008, 2008, 2874-2876.

65. Calder, E.D.; Grafton, M.W.; Sutherland, A. One-pot multi-reaction processes: Synthesis of natural products and drug-like scaffolds. Synlett 2014, 25, 1068-1080. [CrossRef]

66. Wishka, D.G.; Bédard, M.; Brighty, K.E.; Buzon, R.A.; Farley, K.A.; Fichtner, M.W.; Kauffman, G.S.; Kooistra, J.; Lewis, J.G.; O'Dowd, H. An asymmetric synthesis of (2S,5S)-5-Substituted azepane-2-carboxylate derivatives. J. Org. Chem. 2011, 76, 1937-1940. [CrossRef] [PubMed]

67. Zhang, W.; Dong, X.; Zhao, W. Microwave-assisted solventless reaction of iridium-catalyzed alkylation of amines with alcohols in the absence of base. Org. Lett. 2011, 13, 5386-5389. [CrossRef] [PubMed]

68. Sacher, J.R.; Weinreb, S.M. Construction of the azocane (azacyclooctane) moiety of the Lycopodium alkaloid lycopladine $\mathrm{H}$ via an intramolecular hydroaminomethylation strategy. Org. Lett. 2012, 14, 2172-2175. [CrossRef] [PubMed]

(C) 2017 by the authors. Licensee MDPI, Basel, Switzerland. This article is an open access article distributed under the terms and conditions of the Creative Commons Attribution (CC BY) license (http:/ / creativecommons.org/licenses/by/4.0/). 